\title{
DIREITOS HUMANOS, NORMATIVIDADE E PROGRESSISMO: ALÉM DO HEMISFÉRIO OCIDENTAL
}

\author{
HUMAN RIGHTS, NORMATIVITY AND PROGRESSISM: BEYOND \\ THE WESTERN HEMISPHERE
}

Ángel R. Oquendo ${ }^{1}$

\begin{abstract}
RESUMO
O Sistema Interamericano de Direitos Humanos tem passado por uma crise letal profunda. Diversos países liderados por Venezuela, Equador, Bolívia e Nicarágua têm atacado ferozmente os órgãos-chave dele, a saber, a Comissão e a Corte. Poder-se-ia afirmar alternativamente que o desafio subjacente está escorado (1) em noções de soberania ou não-intervenção, (2) num repúdio a decisões específicas ou (3) num apelo à politização dos direitos humanos. A terceira interpretação se apresenta como a mais fidedigna, além de altamente útil para o atual debate internacional sobre esses compromissos com a humanidade. A fim de contas, eles possuem uma dimensão política crucial, porém não exaustiva. $\mathrm{Na}$ verdade, o governo goza de espaço de manobra quanto a eles no que diz respeito à política pública, (em oposição ao princípio puro), mas muito menos do que pretendem os dissidentes governamentais. Algumas controvérsias concretas em torno da liberdade de expressão e da garantia à saúde servirão para ilustrar essa conclusão.
\end{abstract}

PALAVRAS-CHAVE:

Política, princípios, Direitos Humanos, Soberania, Politização.

\begin{abstract}
The Inter-American Human-Rights System is undergoing a deep life-threatening crisis. Several countries led by Venezuela, Ecuador, Bolivia, and Nicaragua have fiercely attacked the key institutions, namely, the Commission and Court. One might alternatively construe the underlying challenge as resting on (1) the notions of sovereignty or nonintervention, (2) a repudiation of certain specific decisions, or (3) a call for the politicization of human rights. The third interpretation comes across as the most accurate, plus as highly helpful for the current international debate on such entitlements. Indeed, these possess a crucial, though nonexhaustive, political dimension. Ultimately, a government deserves deference with respect to the politics or policy, as opposed to the pure principle, pertaining to them but far less than the governmental dissidents claim. A few concrete controversies around free speech and the guaranty of health will serve to illustrate the point.
\end{abstract}

\footnotetext{
${ }^{1}$ Catedrático de Direito George J. e Helen M. England, Universidade de Connecticut; Professor Visitante do Exterior da CAPES, Universidades do Estado e Federal do Rio de Janeiro; Professor Visitante da DAAD, Universidade Livre de Berlin. Ph.D., M.A. (Filosofia), A.B. (Economia e Filosofia), Harvard University; J.D., Yale Law School. O autor agradece a David Abraham, Renata Cunha, David Dyzenhaus, Owen Fiss, James Foreman, Felipe Frisoli, Benjamin Haldeman, Puja Kapai, Rick Kay, Lauren Kinell, Taylor Faranda Korthuis, Lisa Laplant, Molly Land, Dennis Lynch, Ronaldo Macedo, Fábio Morosini, JoNel Newman, Jim Nickel, Joe Page, Eduardo Rêgo, Cristina Rodríguez, Keith Rosenn, Claudia Schubert, Alexandre Veronese, Richard Wilson, e membros do Seminário Latino-americano de Teoria Política e Constitucional da Yale Law School pela sua incalculável contribuição ao desenvolvimento das ideias deste opúsculo.
} 


\section{KEYWORDS:}

Politics, principles, human rights, sovereignty, politicization.

\section{INTRODUÇÃO}

Depois de se evoluir para um regime quase constitucional com amplo reconhecimento da vinculatividade de sua competência e um respeitável registro de cumprimento ${ }^{2}$, o Sistema Interamericano de Direitos Humanos tem passado por profunda crise. Vários países principalmente a porção "bolivariana" ${ }^{3}$ da Venezuela, Equador, Bolívia e Nicarágua ${ }^{4}$ - têm constantemente atacado os seus dois principais órgãos, i.e., a Comissão e a Corte Interamericana de Direitos Humanos, por supostamente ultrapassarem os seus limites. Não é surpresa que figuras de alto perfil tenham liderado esse ataque. Por exemplo, o ex-presidente do Equador, Rafael Correa, tem apontado a Organização dos Estados Americanos (OEA) de ser responsável pela alegada extrapolação de limites e tem insistido em que ela deve "se revolucionar ou desaparecer"5. O Presidente boliviano Evo Morales, por sua vez, tem afirmado que a entidade deve ou "morrer a serviço do império ou renascer com o objetivo de servir aos povos das Américas".6.

Neste artigo, investigarei esse desafiador assunto transcontinental e, por fim, o abordarei como um atraente, embora parcialmente problemático, chamado à politização dos direitos humanos. Em outras palavras, irei construí-lo e analisá-lo tendo como base a asserção de que

\footnotetext{
${ }^{2}$ Ver em geral ÁNGel R. OQUENDO, LATIN AMERICAN LAW 250-251 (2d Ed. 2011).

3 O termo "bolivariano" alude a Simón Bolívar (1783-1830), que teve papel fundamental nas guerras de independência da América Espanhola no século XIX e que se tornou símbolo da luta para a unificação da parte Sul do continente. Ver Simon Romero, Building a New History by Exhuming Bolivar, N.Y. TimES (Aug. 4, 2010), p. A7. A Aliança Bolivariana para as Américas (Alianza Bolivariana para los Pueblos de Nuestra América), por exemplo, promove a cooperação e integração dessas nações bolivarianas a várias ilhas do Caribe, como Antígua e Barbuda, Cuba, Dominica e São Vicente e Granadina. Ver Simon Romero, A Candidate in Peru Tacks Toward Brazil's Course, N.Y. Times (1 de maio de 2011), p. A10 (“A Aliança Bolivariana para as Américas, ou ALBA, é um bloco político liderado pela Venezuela e que inclui Bolívia, Cuba e Nicarágua.”).

${ }^{4}$ A Nicarágua tem realizado um papel de menor importância. Venezuela, Equador e Bolívia, por sua parte, têm assumido, como este artigo destaca, algumas posições excêntricas na controvérsia. Por exemplo, enquanto a Venezuela decidiu abandonar o Sistema, o Equador tem feito propostas específicas para uma reforma e a Bolívia tem se ocupado em fazer afirmações gerais em suporte à posição do grupo. No entanto, todos os quatro países têm insistido em se apresentar como um bloco e, dentro do possível, coordenado suas ações.

${ }^{5}$ Mabel Azcui, El presidente Correa dice que la OEA debe “revolucionarse o desaparecer, ” EL PAÍs (5 de jun. de 2012) (citando o expresidente equatoriano Rafael Correa).

${ }^{6}$ Mabel Azcui, Evo Morales: “La OEA puede morir al servicio del imperio o renacer,” EL PAís (4 de jun. de 2012).
} 
os juízes internacionais devem deferir aos governos, especialmente àqueles que estiverem implementando tais direitos como parte de um projeto mais amplo de emancipação social.

Os críticos das estruturas regionais de direitos humanos não se limitam a uma firme retórica. Eles também condenam, com particular agressividade, certas determinações e decisões desfavoráveis ${ }^{7}$. A coalisão dos dissidentes tem proposto, além de impedir a Comissão da faculdade para "adotar medidas cautelares em proteção de potenciais vítimas" ou para "receber petições individuais" de modo amplo ${ }^{8}$, impedir que os Estados que não ratificaram os principais tratados de direitos humanos, como os Estados Unidos da América e o Canadá, nomeiem Comissários 9 .

Autoridades equatorianas têm desenvolvido suas próprias demandas, como o fim da chamada lista negra de regimes delinquentes, presente no Capítulo IV do Relatório Anual da Comissão e a realocação da sede da Comissão de Washington para Buenos Aires ${ }^{10}$. Ainda, submeteram uma proposta escrita, em 2011, solicitando que a Organização dos Estados Americanos (1) acolhesse "o quanto antes" a "política" de financiar o "Sistema Interamericano de Direitos Humanos" somente com "recursos" internos, (2) proibisse imediatamente o recebimento de doações de entidades alheias à Organização e com destinação pré-determinada e (3) equalizasse os fundos disponíveis bem como a exposição de que gozam vários "Relatorias" da Comissão ${ }^{11}$. Na mesma proposta, o Equador enfatizou que os órgãos de decisão devem tratar “todos os Estados" igualmente e efetivar "não apenas direitos políticos e civis, mas também econômicos, sociais e culturais" $"$.

Após reclamar formalmente do enviesamento da Comissão, da sua "politização", e "parcialidade"13, a Venezuela exerceu o seu direito contido no Artigo 78 de denunciar a

\footnotetext{
${ }^{7}$ Ver infra Seção I(B).

${ }^{8}$ Ver Eva Sáiz, La OEA, dividida ante la reforma de su órgano de derechos humanos, El PAÍS (7 de dez. de 2012).

${ }^{9}$ Ver César Gaviria Trujillo, Mordaza a un líder de la libertad de expresión, El PAÍs (20 de mar. de 2013).

${ }^{10}$ Ver Eva Sáiz, El ALBA afronta aislado la reforma del sistema de derechos humanos de la OEA, EL PAÍS (21 de mar. de 2011); "La reforma del sistema de protección de derechos de la OEA no ha concluido," EL PAís (22 de mar. de 2011); La OEA cierra en falso la reforma del su sistema de derechos humanos, EL PAís (23 de mar. de 2011).

${ }^{11}$ Propuestas de la Delegación del Ecuador sobre los Temas "Financiamiento", "Universalidad", "Asuntos de Procedimiento" e "Informe Anual de la CIDH", submetidas ao Grupo Especial de Trabalho da Comissão Interamericana de Direitos Humanos e para o Fortalecimento do Sistema Interamericano de Direitos Humanos, OEA/SER. G, GT/SIDH/INF. 46/11 (5 de dez. de 2011).

${ }^{12} I d$.

13 Propuestas de la Delegación de República Bolivariana de Venezuela Sobre el Tema "Criterios Para la Construcción del Capítulo IV del Informe Anual de la Comisión Interamericana de Derechos Humanos (CIDH), ”
} 
Convenção Americana de Direitos Humanos ${ }^{14}$. Em 2012, o país introduziu uma Nota Denunciativa assinada por Nicolás Maduro, então Ministro das Relações Exteriores e atualmente Presidente, e que se tornou efetiva em 6 de setembro de $2013^{15}$. Equador e Bolívia têm ameaçado seguir a mesma linha ${ }^{16}$.

"Outros países, como a Colômbia e Costa Rica", têm se distanciado e dado suporte à instituição sob ataque ${ }^{17}$. Eles têm "defendido que a Comissão deve preservar o seu caráter autônomo e internacional" ${ }^{\text {"18 }}$. O Secretário de Estado Norte-americano, John Kerry, assinalou que os Estados Unidos têm uma posição semelhante:

\begin{abstract}
Nós temos escutado muitas coisas sobre a Comissão ultimamente e eu acho isso bom, na verdade. Diálogo é uma parte essencial da democracia e nós queremos melhorar a Comissão. Mas nós precisamos ter em mente que o Sistema Interamericano de Direitos Humanos tem feito uma diferença marcante. Ele tem promovido tanto a democracia representativa quanto as liberdades fundamentais, os princípios pelos quais os membros da OEA são conhecidos. Quando melhoramos a democracia na região, quando nos posicionamos contra restrições de direitos humanos, quando pressionamos por mais oportunidades, nós estamos agindo em solidariedade a todos os povos da região. ${ }^{19}$
\end{abstract}

Mais diretamente, César Gaviria, ex-presidente da Colômbia e antigo Secretário-Geral da Organização dos Estados Americanos, afirmou que as alterações institucionais requeridas

submetidas ao Grupo Especial de Trabalho da Comissão Interamericana de Direitos Humanos e para o Fortalecimento do Sistema Interamericano de Direitos Humanos, OEA/Ser. G/GT/SIDH/INF. 44/11 (2011).

${ }^{14}$ Ver Convenção Americana de Direitos Humanos, art. 78, 22 de nov. de 1969, O.A.S.T.S. No. 36, 1144 U.N.T.S 123.

${ }^{15}$ Nicolás Maduro Moros, Ministro de Relaciones Exteriores de la República Bolivariana de Venezuela, Carta a José Miguel Insulza, Secretario General de la Organización de Estados Americanos (6 de set. de 2012) (arquivo do autor). Na Fundamentação, as autoridades venezuelanas também condenaram de forma geral a Comissão pela sua parcialidade e falta de detalhamento no processo de determinação dos países que devem estar sujeitos a monitoramento especial (lista negra); também pela sua consideração de fatos hipotéticos, e pela falta de critério na recepção de medidas preventivas e petições individuais. Nicolás Maduro Moros, Ministro de Relaciones Exteriores de la República Bolivariana de Venezuela, Fundamentación que sustenta la denuncia de la República Bolivariana de Venezuela de la Convención Americana sobre Derechos Humanos presentada a la Secretaría General de la OEA 1-3 (2012).

${ }^{16}$ Eva Sáiz, La OEA cierra en falso la reforma del su sistema de derechos humanos, EL PAís (23 de mar. de 2013); Eva Sáiz, El ALBA afronta aislado la reforma del sistema de derechos humanos de la OEA, EL PAÍs (21 de mar. de 2013); Eva Sáiz, La OEA, dividida ante la reforma de su órgano de derechos humanos, El PAÍs (7 de dez. de 2012); Mabel Azcui, El eje bolivariano ataca la Comisión Interamericana de Derechos Humanos, EL PAÍs (6 de jun. de 2012).

${ }^{17}$ Mabel Azcui, El eje bolivariano ataca la Comisión Interamericana de Derechos Humanos, El PAís (6 de jun. de 2012).

${ }^{18} I d$.

${ }^{19}$ Comunicado à Imprensa, John Kerry, Sec'y of State, U.S. State Department, Solo Press, Comments at the Organization of American States (6 de jun. de 2013). 
pelos regimes descontentes "iria gravemente debilitar a Comissão e abrir caminho para que governos desrespeitem direitos básicos e restrinjam a liberdade de expressão". ${ }^{20}$

Em março de 2013, a Organização dos Estados Americanos, em sessão plenária, rejeitou em peso a reforma propugnada pelas autoridades equatorianas ${ }^{21}$. Entretanto, decidiu instruir o seu Conselho Permanente a "continuar o diálogo sobre aspectos fundamentais para o fortalecimento do Sistema Interamericano de Direitos Humanos"22. De fato, a Argentina ofereceu e pressionou pela aprovação dessa resolução como resposta à "ameaça do Equador . .. de abandonar o Sistema",23.

Sem dúvida, o confronto mencionado representa um momento definidor para o hemisfério ocidental. Pode transformar ou até subverter o atual sistema de direitos humanos. A região pode quedar-se com uma multiplicidade de microssistemas ou, no pior caso, regredir a uma situação de efetivação meramente nacional de direitos.

Toda essa confrontação fornece uma oportunidade única à comunidade internacional para uma reflexão sobre a natureza dos direitos humanos. Este escrito aproveitará essa situação e tomará um passo nessa direção. Tratará de questões como as seguintes: Que papeis exercem princípios e políticas, respectivamente, na concretização de direitos humanos? Em qual extensão um grupo de nações com ideologias diversas pode trabalhar junto para a implementação de tais direitos? Qual lugar, se algum, estes devem ocupar num projeto de emancipação política?

Este trabalho irá reformular esse conflito transcontinental como uma disputa criptofilosófica sobre a natureza dos direitos humanos. Refutará os argumentos da aliança esquerdista de que tais direitos consistem em políticas progressistas. Sob essa perspectiva, o governo de cada país estabelece uma agenda política e os juízes, nacionais ou internacionais, deveriam reagir de forma a apoiar, ao invés de criticar, tais ações.

A Parte I identificará as nuances da reivindicação bolivariana. Analisará três formulações alternativas com o intuito de determinar se elas estão corretas e se são relevantes

\footnotetext{
${ }^{20}$ César Gaviria Trujillo, Mordaza a un líder de la libertad de expresión, EL PAÍs (20 de mar. de 2013).

${ }^{21}$ Eva Sáiz, La OEA cierra en falso la reforma del su sistema de derechos humanos, EL PAís (23 de mar. de 2013).

${ }^{22}$ Id. (citando "texto final" da resolução submetida pela Argentina e adotada pelo Conselho Permanente da OEA).

${ }^{23} I d$.
} 
para o atual debate internacional sobre os direitos humanos. A Parte I contemplará inicialmente se o pedido se baseia principalmente (A) em noções de soberania e não-intervenção ou (B) num repúdio a certas decisões da Comissão e da Corte. Ao descartar essas duas possibilidades, interpretará o citado posicionamento, ao contrário, como (C) um apelo pela politização dos direitos humanos. Inevitavelmente, a interpretação terá a forma de uma reconstrução.

A Parte II, por sua vez, fará uma crítica à reivindicação. Irá (A) se recusar a associar direitos humanos unicamente a princípios e (B) reconhecer a essencial, mas não absoluta, dimensão política de tais direitos. Depois de destacar a importância dos dois âmbitos, a Parte II (C) argumentará que os representantes estatais devem ter liberdade quanto à política, mas não na intensidade desejada pelos Estados dissidentes. Em seguida, (D) exemplificará o posicionamento com a análise de casos que envolvem liberdade de expressão e direito à saúde.

Além de revisar toda discussão, a Conclusão trará algumas considerações finais. Primeiro, quando um governo aumenta seu engajamento em favor dos direitos humanos, ele passa a depender mais de políticas e, consequentemente, amplia sua margem de discricionariedade. Contudo, os tribunais não devem fugir do seu dever de controlar a arbitrariedade. Tampouco devem negligenciar o controle de qualquer violação de princípios.

Segundo, a almejada busca pela justiça social, às vezes, colide com os direitos humanos. Entretanto, isso ocorre excepcionalmente. Portanto, um regime profundamente engajado com a criação de uma sociedade justa não precisa nem merece ter carta branca em relação a esses direitos.

Terceiro, o autoproclamado Eixo Bolivariano ${ }^{24}$ e seus oponentes parecem concordar que os direitos humanos envolvem ou princípios deontológicos ou política teleológica. Além disso, eles parecem ter convergido numa sorte de utopia de acordo com a qual o Executivo e o Judiciário devem lidar conjuntamente com esses direitos, com uma das duas instituições

\footnotetext{
${ }^{24} \mathrm{O}$ antigo Presidente venezuelano Hugo Chávez frequentemente usava a expressão "Eixo Bolivariano" ("eje bolivariano") para se referir à sua aliança com regimes ideologicamente semelhantes na região. Ele ainda brincava com a conotação negativa da palavra "eixo". De fato, ainda se declarava parte de um "eixo do mal", gozando da oratória de George W. Bush. Ver, e.g., Chávez se incluye en el eje del mal, LA NACIÓN (28 de jun. de 2010). A denominação "Eixo Bolivariano", nesse sentido, data de 2005, pelo menos. Ver Mercedes Gallego, Comienza a llegar la primera ayuda federal a las zonas devastadas por el "Katrina," ABC (9 de abr. de 2005) ("Fidel Castro se juntou ... à iniciativa lançada pelo 'Eixo Bolivariano', que o seu amigo, o Coronel Hugo Chávez, lidera.”). Ver também RichaRd LAPPER, VENEZUELA AND THE RISE OF CHAVEZ: A BACKGROUND DisCUSSION PAPER § 3.3, COUNCIL ON FOREIGN RELATIONS (22 de novembro de 2005) ("Chávez fala sobre construir um Eixo Bolivariano na América Latina.”).
} 
liderando o caminho e a outra apenas acompanhando. A divergência ocorre, aparentemente, apenas quando se discute se o juiz deve se curvar ao Estado, dado que este é um especialista em política, ou o contrário, já que a especialidade do Judiciário é a interpretação de normas. Como notado anteriormente, entretanto, os direitos humanos tocam tanto em princípios quanto em políticas. E mais, autoridades políticas e jurídicas participam igualmente na salvaguarda desses direitos. Inevitavelmente, se envolvem numa luta de poder nessa fronte e devem, como resultado, aceitar o conflito como algo que faz parte das suas essências.

\section{IDENTIFICAÇÃO DA REIVINDICAÇÃO}

\section{A. SOBERANIA E NÃO-INTERVENÇÃO}

À primeira vista, os Estados dissidentes da Organização dos Estados Americanos parecem levantar a tradicional argumentação em torno da soberania e da não-intervenção. Em outras palavras, poderiam estar negando a legitimidade dos direitos humanos internacionais. Sob essa perspectiva, a comunidade de nações não deve objurgar a forma com que os governos tratam seus cidadãos ${ }^{25}$.

Por vezes os detratores caracterizaram a campanha bolivariana em nesses exatos termos. Por exemplo, José Miguel Vivanco, Diretor da Divisão das Américas da Human Rights Watch ${ }^{26}$, retratou o movimento como uma cruzada liderada por "governos nostálgicos da soberania e pelo princípio da não-intervenção", "para descreditar e enfraquecer a Comissão ${ }^{27}$. De fato,

\footnotetext{
${ }^{25}$ O governo britânico aparentemente reclamou do Sistema Europeu de Direitos Humanos nos mesmos termos. Ver, e.g., Estelle Shirbon, British Minister Floats Quitting European Rights Convention, REUTERS ( 9 de mar. de 2013) (Afirmação de que "O Partido Conservador tem criticado há bastante tempo a Corte Europeia de Direitos Humanos (ECHR), que aplica a convenção, como uma limitadora da soberania britânica.").

${ }^{26}$ Em 2008, o governo venezuelano "prendeu" e "expulsou" Vivanco depois que ele e seu Vice-Diretor, Daniel Wilkinson, "lançaram um longo relatório . . . documentando violações de direitos humanos na Venezuela." Simon Romero, Venezuela Expels 2 After Human Rights Report, N.Y. TIMES (20 de set. de 2008), p. A8. Ver também Clodovaldo Hernández, Venezuela expulsa al director del informe crítico con Hugo Chávez, El PAís (20 de set. de 2008).

${ }^{27}$ José Miguel Vivanco, Derechos Humanos, Insulza, Brasil y el ALBA, El PAís (3 de jun. de 2012).
} 
Vivanco condenou todo o esforço como uma tentativa de minar e, se possível, abolir o Sistema Interamericano de Direitos Humanos ${ }^{28}$.

Ocasionalmente, as manifestações das nações em questão parecem sustentar essa caracterização. A Denúncia da Venezuela, por exemplo, acusa a Comissão e a Corte de "ações intervencionistas", com a violação de princípios básicos e essenciais - amplamente defendidos pelo direito internacional - como o princípio da soberania estatal ${ }^{29}$. Nos dois últimos parágrafos, o instrumento invoca, de novo, conceitos de não-intervenção e "soberania"30. Similarmente, a Fundamentação rotula alguns dos últimos trabalhos da Comissão "como uma afronta à soberania do Estado venezuelano"31. Finalmente, refere-se à "soberania legislativa da nação" e à "soberania" que "inalienavelmente reside no Povo"32.

Em realidade, os governos dissidentes não estão baseando suas objeções majoritariamente em noções de soberania estatal e não-intervenção. Até porque eles estão pleiteando uma reforma, não a erradicação do aparato de direitos humanos existente. É significativo que o debate tenha sido realizado, em parte, num "Grupo Especial de Trabalho" destinado expressamente, como o próprio nome indica, ao "Fortalecimento do Sistema Interamericano de Direitos Humanos" ${ }^{\prime 3}$. Se o clamor pela mudança não for atendido, o bloco de esquerda insiste que não irá abrir mão dos direitos em jogo, mas que criará um regime alternativo de direitos humanos. ${ }^{34}$

Mostrando disposição para ceder privilégios soberanos ante os direitos humanos internacionais, a mencionada Nota Denunciativa da Venezuela descreve (1) a ratificação "da Convenção Americana de Direitos Humanos" e (2) a institucionalização de "mecanismos" para "a promoção e proteção dos direitos humanos" como "muito importantes" para "região" 35. No mesmo instrumento, a Venezuela se orgulha de ter ratificado o tratado antes de qualquer outro Estado, fazendo-o "por uma declaração unilateral", e sendo o segundo país "a aceitar a

\footnotetext{
${ }^{28} I d$.

${ }^{29}$ Maduro Moros, Carta, supra nota 15, p. 2.

${ }^{30} I d$., p. $9-10$.

${ }^{31}$ Maduro Moros, Fundamentación, supra nota 15, p. 2.

${ }^{32} I d$., p. 2, 22.

${ }^{33}$ Ver, e.g., Propuestas de la Delegación del Ecuador, supra nota 11.

${ }^{34}$ Ver Eva Sáiz, La OEA, dividida ante la reforma de su órgano de derechos humanos, EL PAís (7 de dez. de 2012) (Os "presidentes" de Bolívia e Equador, Evo Morales e Rafael Correa, alertaram que [seus países] podem se retirar do Sistema Interamericano de Direitos Humanos e que estavam considerando a criação de um corpo similar sob a União Sul-americana de Nações.”).

${ }^{35}$ Maduro Moros, Carta, supra nota 15, p. 1.
} 
jurisdição da Corte [Interamericana]"..36 Além disso, chama atenção para amplitude de direitos humanos abrigados pela sua própria Constituição de $1999^{37}$.

Apesar de denunciar a Convenção Americana, as autoridades venezuelanas simultaneamente se comprometem, em sua proposta, a respeitar e colaborar "com outros mecanismos . . . pela promoção e proteção dos direitos humanos. . .."38. Presumidamente falando para si mesmos e aos aliados na região, também "expressam a firme intenção . . . de contribuir para a construção do Nosso Próprio Sistema de Direitos Humanos e Populares. . . „39. Com essas palavras, o documento reitera a intenção de construir um novo esquema de direitos humanos em razão do declarado repúdio às estruturas existentes. Coincidentemente, também parece revelar um certo ceticismo quanto à possibilidade de Estados ideologicamente diversos trabalharem juntos na defesa de tais direitos.

Com certeza, Venezuela, Equador, Bolívia e Nicarágua teriam se situado de forma diferente caso pretendessem rejeitar os direitos humanos em razão de uma suposta afronta à sua soberania. Teriam simplesmente anunciado sua iminente denunciação da Convenção e talvez uma eventual saída da Organização dos Estados Americanos. Nesse anúncio, entretanto, não constariam exigências de reforma, nem mesmo votos de lançar um novo sistema.

Assim sendo, esses países não estão questionando a exigibilidade internacional desses direitos frente aos Estados soberanos. Claro, possivelmente estejam se apresentando falsamente como reformistas, como devotos dos direitos humanos e como possíveis construtores de um corpo paralelo de direitos humanos. Contudo, esta Parte se ocupa de interpretar as argumentações do grupo, não em adivinhar seus potenciais objetivos.

De qualquer forma, alegações de soberania e não-intervenção pouco contribuiriam à discussão transnacional sobre direitos humanos. Na metade do século passado, tais asserções poderiam ter convencido muitas pessoas. Atualmente, entretanto, parecem bem menos atraentes.

\footnotetext{
${ }^{36} I d$.

${ }^{37} I d$.

${ }^{38} I d .$, p. 9.

${ }^{39} I d .$, p. 10.
} 
Alguns dos principais tratados assinados depois da Segunda Guerra Mundial afirmam que os Estados não têm apenas a autoridade, mas também o dever de impedir que um Estado limite as liberdades dos seus cidadãos ${ }^{40}$. Esses acordos refletem tanto uma mudança de consenso, como também uma interessante construção de interrelações entre o mundo, as nações e os indivíduos. Desse ponto de vista, uma violação de direitos fundamentais de uma pessoa em qualquer país constitui uma questão internacional ao invés de doméstica.

De forma mais ampla, o direito internacional como um todo se baseia atualmente na noção de direitos humanos universais. Tais direitos possuem um papel crítico na definição da esfera de ação legítima dos atores globais. Pressentindo essa mudança de paradigma, a Carta das Nações Unidas se inicia com um pedido para:

reafirmar a fé nos direitos fundamentais do homem, na dignidade e no valor do ser humano, na igualdade de direito dos homens e das mulheres, assim como das nações grandes e pequenas, e . . . estabelecer condições sob as quais a justiça e o respeito às obrigações decorrentes de tratados e de outras fontes do direito internacional possam ser mantidos, e . . promover o progresso social e melhores condições de vida dentro de uma liberdade ampla. ${ }^{41}$

Essa afirmação evoca uma comunidade internacional direta e completamente preocupada com os direitos básicos das pessoas em qualquer lugar.

A respeito disso, o fato de várias nações tão incomodadas pelo trabalho da Corte e Comissão Interamericana se sentirem, no entanto, compelidas a proclamar sua ligação aos direitos humanos merece atenção. Isso demonstra que tais direitos alcançaram um alto grau de respeito e reconhecimento. De fato, percorreram um longo caminho na sua relativamente curta história.

Claro, os Estados geralmente têm o dever de respeito a um direito humano específico somente até onde, como soberanos, concordaram em fazê-lo pela ratificação de relevantes instrumentos, seja um tratado ou a Carta da $\mathrm{ONU}^{42}$. Pela mesma razão, podem se recusar a participar de qualquer sistema de direitos humanos potencial ou existente. Todavia, facção

\footnotetext{
${ }^{40}$ Ver, e.g., International Covenant on Civil and Political Rights, 23 de mar. de 1976, 999 U.N.T.S. 171; International Covenant on Economic, Social and Cultural Rights, 16 de dez. de 1966, 993 U.N.T.S. 3.

${ }^{41}$ Carta das Nações Unidas pmbl.

${ }^{42} \mathrm{Ver}$, e.g., id. art. 2, II 1 ("A Organização é baseada no princípio da igualdade soberana de todos os seus membros."); id. art. 2, II 2 ("Os membros da Organização, a fim de assegurarem a todos em geral os direitos e vantagens resultantes da sua qualidade de membros, deverão cumprir de boa fé as obrigações por eles assumidas. ..."); $i d$. art. 2, If 7 ("Nenhuma disposição da presente Carta autorizará as Nações Unidas a intervir em assuntos que dependam essencialmente da jurisdição interna de qualquer Estado....").
} 
bolivariana não parece estar buscando tal curso de ação. Nem atrairia muita atenção internacional caso estivesse.

A propósito, uma nação pagaria um preço muito alto para exercer a totalidade da sua soberania e abjurar todos os direitos humanos. Teria que se desligar das Nações Unidas assim como da maioria das instituições e arranjos globais. Certamente outras nações também iriam condená-la e talvez aplicar sanções.

Além disso, alguns direitos humanos continuam a ser aplicados como normas peremptórias (jus cogens) ${ }^{43}$. Para ser mais exato, uma nação poderia tornar tais direitos inaplicáveis apenas caso se isolar e der as costas ao restante do mundo. Assim, atrairia para si não uma isenção, mas, no melhor dos casos, o status de quem os recusa intencionalmente ou, no pior, o de uma espécie de fora-da-lei global.

De forma geral, uma interessante concepção de Estado como uma entidade autodeterminada, implicada numa complexa e intrincada rede de relações e compromissos com indivíduos e coletividades, tem gradual, mas decisivamente, substituído aquela do Estado como um ente absolutamente soberano e voltado somente para si. Nesse sentido, as nações devem esperar ser questionadas quando tratarem seus cidadãos de forma arbitrária. E mais, devem honrar suas responsabilidades em relação a uma ampla gama de entidades públicas e privadas, tanto domésticas quanto internacionais, enquanto atuam de forma autônoma, resistindo à heteronomia ou dominação ${ }^{44}$.

\footnotetext{
${ }^{43}$ Ver, e.g., A Condição Jurídica e os Direitos dos Migrantes Indocumentados, Parecer Consultivo, OC-18/03, Ct. Inter-Am. D.H. (Ser. A) No. 18 (17 de set. de 2003), p. 117 (II 101) (“[O] princípio de igualdade perante a lei, igual proteção perante a lei e não discriminação, pertence ao jus cogens, já que sobre ele descansa todo o arcabouço jurídico da ordem pública nacional e internacional e é um princípio fundamental que permeia todo ordenamento jurídico. . . . Na atual etapa da evolução do Direito Internacional, o princípio fundamental de igualdade e não discriminação ingressou no domínio do jus cogens.").

${ }^{44}$ Ver, e.g., IRIS Marion Young, Two Concepts of Self-Determination, in Global Challenges: War, SelfDETERMINATION, AND RESPONSIBILITY FOR JUSTICE 50-51 (2007). Young escreve que "autodeterminação para os povos significa que eles têm direito a instituições de governo próprios por meio das quais eles decidem seus objetivos e definem um modo de vida." Id., p. 50 "Porque um povo permanece em relações interdependentes com outros," ela alerta, "um povo não pode ignorar os clamores e interesses de outros quando suas ações potencialmente as afetar." Id., p. 51 Além disso, Young afirma: "Um conceito relacional de autodeterminação para os povos não implica que os membros de um grupo podem fazer qualquer coisa que quiserem a outros membros sem sofrer interferência externa." Id., p. 57. Ela conclui dizendo que "Isso implica que enquanto houver regras globais definindo direitos individuais e agentes para aplicá-las, todos os povos devem ter o direito de serem representados como povos nos fóruns que definem e defendem esses direitos." Id.
} 
Nem é preciso dizer que os Estados contemporâneos frequentemente violam seus deveres transnacionais, sejam os assumidos voluntariamente ou os impostos internacionalmente. Às vezes, lidam com seus cidadãos de forma não menos brutal que os seus antecessores antes de 1945. Não é surpresa que o surgimento de um consenso de que os direitos humanos se aplicam a todas as nações ainda não tem produzido um cumprimento total.

Além do mais, se poderia argumentar, os regimes nacionais geralmente manipulam por vezes com a bênção das Nações Unidas - o discurso dos direitos humanos para alcançar um fim desonroso ou mesmo desprezível. Ainda, dedicam-se a sancionar, atacar ou invadir seus inimigos enquanto expulsam, exoneram e defendem tanto a si mesmos quanto aos seus semelhantes. No entanto, qualquer um, especialmente uma vítima, pode apelar aos mesmos direitos com o intuito de cessar essa manipulação ou violação e lutar para a concretização deles.

Em resumo, uma tentativa de ressuscitar o modelo de soberania e de reformular assim a reivindicação bolivariana dificilmente seria persuasiva ou interessante. Enfim, as nações não podem ignorar os direitos humanos de forma discricionária. Tais direitos vinculam os Estados crucial e compulsoriamente. Os membros dissidentes da Organização dos Estados Americanos devem reconhecer tal fato. Enquanto eles geralmente invocam suas prerrogativas como soberanos, assim como a noção de não-intervenção, evidentemente não estão - e definitivamente não devem estar - negando o caráter compulsório dos direitos humanos.

\section{B. TOMADA DE DECISÃO}

Por outro lado, o Eixo Bolivariano poderia estar apenas expressando sua desaprovação em relação à tomada de decisão no Sistema Interamericano de Direitos Humanos. Poderia estar percebendo que os órgãos competentes erram de forma recorrente na solução de controvérsias. As nações descontentes poderiam estar questionando exatamente esses erros.

De fato, a aliança de esquerda tem objetado vigorosamente algumas omissões da Corte e da Comissão. O Presidente do Equador, Rafael Correa, por exemplo, tem declarado abertamente o seguinte:

Infelizmente, vemos que o Sistema Interamericano não está ao nível da mudança de época. Não tem sido capaz de dar soluções ou, pelo menos, posições contundentes e 
decisivas a problemas como as colônias na América. Refiro-me às Ilhas Malvinas, ou como o embargo criminoso. por meio século, a um país irmão, $\mathrm{Cuba}^{45} \ldots$.

O Sistema, de acordo com Correa, não tem feito nem "coisas simples como julgar os responsáveis pelo golpe de Estado contra o presidente [de Honduras] Manuel Zelaya."46

De forma semelhante, o governo da Venezuela reclamou, na sua denunciação, do silêncio da Comissão em face de dois massacres ocorridos na Venezuela na década de 1980. Também condenou o desprovimento de medidas preventivas em favor do antigo Presidente Hugo Chávez durante o golpe de 2002. Além disso, censurou o alegado apoio implícito da Comissão ao regime insurgente ${ }^{47}$.

A Comissão e a Corte podem ter falhado em alguma dessas instâncias. De todo modo, nunca receberam uma reclamação formal que as possibilitassem de se debruçar sobre essas questões. Enfim, dificilmente falar-se-ia de um posicionamento equivocado de ambos.

Certamente os Comissários deveriam ter concedido qualquer remédio preliminar que pudesse ter sido requisitado contra a deposição de Chávez em 2002. Na verdade, eles não tiveram tempo hábil para atuar, já que o líder deposto retomou o poder em apenas quarenta e oito horas ${ }^{48}$. Como resultado, a matéria se tornou acadêmica instantaneamente.

Além do mais, a Comissão marcou para "imediatamente após a ruptura institucional de abril de 2002," uma visita à Venezuela em maio de $2002^{49}$. Em último ato, em 13 de abril, dois dias depois da insurreição, liberou uma nota de imprensa instando "a um rápido retorno ao Estado de Direito e ao sistema democrático de governo". ${ }^{50}$ De forma conspícua, entretanto, os Comissários não demandaram a restauração do legítimo chefe de Estado. ${ }^{51}$

\footnotetext{
${ }^{45}$ Mabel Azcui, El presidente Correa dice que la OEA debe “revolucionarse o desaparecer,” EL PAÍs (5 de jun. de 2012) (citando o presidente equatoriano Rafael Correa).

${ }^{46} I d$.

${ }^{47}$ Maduro Moros, Carta, supra nota 15, pp. 4-5.

${ }^{48}$ Ver em geral Larry Rohter, Venezuela's 2 Fateful Days: Leader Is Out, and In Again, N.Y. TIMES (20 de abr. de 2002), p. A1.

${ }^{49}$ Comisión [Cms.] Inter-Am. D.H., Democracia y Derechos Humanos en Venezuela, OEA/Ser. L./V./II. (Doc. 54) (30 de dez. de 2009), p. 1 (Intro.) (II 3).

${ }^{50}$ Comunicado à Imprensa, Cms. Inter-Am. D.H., Sobre los sucesos en Venezuela 1 (13 de abr. de 2002).

${ }^{51} \mathrm{O}$ documento meramente "deplora a demissão remoção . . . das mais altas autoridades judiciais e autoridades independentes do Executivo, bem como a cessação do mandato dos membros do Poder Legislativo." Id. Ele adicionalmente clama pela "organização de eleições." Id.
} 
A Organização dos Estados Americanos e alguns outros órgãos responderam rapidamente à rebelião. Por exemplo, a Comissão Permanente logo adotou uma inequívoca resolução condenatória. Condenou "a alteração da ordem constitucional na Venezuela" e pressionou pela "normalização da institucionalidade democrática . . . no marco da Carta Democrática Interamericana." 52 Presumivelmente, esse pedido implicava a restituição de Chávez e seu governo.

Mais uma vez, a Comissão Interamericana e a Corte não confrontaram um caso concreto que pudessem ter resolvido oportunamente ou que tivessem julgado de modo equivocado. De toda forma, a Comissão poderia ter agido, sua sponte, por meio da sua competência de investigação e acusação com o intuito de reprovar, ex post facto, a insurreição venezuelana de 2002. Também poderia ter agido de forma significativa em relação à ocupação britânica das Ilhas Malvinas, ao embargo estadunidense à Cuba, ao golpe contra o então Presidente de Honduras Zelaya, e aos assassinatos na Venezuela na década de 1980. O grupo bolivariano poderia estar lamentando a falha dos Comissários em fazê-lo.

De fato, o próprio Presidente da Venezuela, Hugo Chávez, se concentrou no Relatório da Comissão em 2010 quando orientou a sua administração a repudiar a Convenção Americana de Direitos Humanos. Ele focou no que os Comissários escreveram ao invés do que omitiram de mencionar. Destaca-se que eles alertaram "para a deterioração da democracia da Venezuela."53

Chávez contra-atacou o documento em termos fortes: "É puro lixo. Deveríamos nos preparar para denunciar o acordo por meio do qual a Venezuela aderiu (ou como seja que se fale) à nefasta Comissão Interamericana de Direitos Humanos e sair dali porque não vale à pena." 54

Sem dúvida, a Comissão poderia ter amenizado sua censura à Venezuela. Contudo, não utilizou palavras particularmente duras. Os comentários às violações imputadas à Venezuela

\footnotetext{
${ }^{52}$ Cms/ Permanente, (OEA.), Resolução: Situación en Venezuela, CP/RES. 811 (1315/02) (13 de abr. de 2002).

${ }^{53}$ Maye Primera, Chávez ordena la salida de Venezuela de la CIDH, El PAís (26 de fev. de 2010). O relatório de 2010 incluiu a Venezuela, no seu controverso Capítulo IV, entre "os países que atraíram especial atenção da Comissão ao longo do . . ano.” Cms. Inter-Am. D.H., Rel. Anual 2010 (Ch. IV), OEA/Ser. L/V/II., Doc. 5 corr. 1 (2011) (Intro.) (\$ 1).

${ }^{54}$ Maye Primera, Chávez ordena la salida de Venezuela de la CIDH, El PAís (26 de fev. de 2010) (citando o presidente venezuelano Hugo Chávez).
} 
são semelhantes aos dirigidos a outras nações listadas no Capítulo IV naquele ano: Colômbia, Cuba e Honduras. ${ }^{55}$

Especificamente, os Comissários concluíram solicitando que a Venezuela não apenas se abstenha "de retaliar ou usar o poder punitivo do Estado para intimidar ou punir pessoas em virtude da sua opinião política", mas também garanta "a pluralidade de espaços para o exercício democrático." 56 Não obstante, o Relatório também focou no lado positivo. Por exemplo, "reconhece e aprecia o progresso alcançado nas áreas de direitos econômicos, sociais e culturais" ${ }^{" 57}$ e inclui uma subseção inteira no tópico, ${ }^{58}$ destacando as conquistas do Estado na redução da pobreza, desigualdade e desemprego. ${ }^{59}$

De fato, a reprimenda citada, como as relatadas condenações não realizadas, não constitui uma decisão judicial ou algo do tipo. Tais pronunciamentos gerais, pelo contrário, fazem parte da função de relatoria da Comissão. Portanto, não vinculam o Estado analisado, ou qualquer outra parte, e tipicamente o levam a protestar, não a subverter o sistema.

O bloco dissidente trata dessa suposta equivocação nos relatórios dos Comissários como um sinal de uma profunda falha sistêmica, afirmando que ela deriva de uma concepção errada da política dos direitos humanos, no sentido exposto na próxima seção. Acredita que as instituições interamericanas deveriam abraçar a perspectiva dele sobre esses direitos. Ao menos, deveriam se abster de censurar e deixar de registrar em uma lista negra os governos progressistas.

De qualquer forma, o resto do mundo certamente não teria muito motivo para prestar atenção nos protestos nacionais contra os relatórios críticos do Sistema Interamericano de Direitos Humanos. Se tomasse conhecimento de todos eles, provavelmente os consideraria como possuidores de interesses principalmente locais. Um clamor dos regimes latinoamericanos de esquerda contra os relatórios da Comissão indubitavelmente revelaria uma verdade universal, mas banal no seguinte sentido: os países não gostam de ser criticados.

\footnotetext{
${ }^{55}$ Ver em geral Cms. Inter-Am. D.H., Rel. Anual 2010, supra nota 53.

${ }^{56}$ Id., p. 606 (II 836(2)) (Venezuela) (\$ VII) (Recomendaciones).

${ }^{57}$ Id., p. 598 (I 834) (Venezuela) (§ VI) ("Los derechos económicos, sociales y culturales").

${ }^{58} I d$., p. 604-05 (II 829-35).

${ }^{59}$ Id. (III 831-832). Vem em geral id., p. 536 (Venezuela) (II 612)) (“Da mesma forma, no Relatório de 2009, a Comissão destacou as importantes conquistas do Estado venezuelano em termos de direitos econômicos, sociais e culturais. ...”).
} 
De todo modo, o Estado venezuelano, na sua Nota Denunciante e no Memorando de Fundamento, não se concentra nos relatórios dos Comissários, mas em seis casos concretos. Acusa a Comissão e a Corte de admitirem petições em matérias que tribunais nacionais ou estavam examinando ou nunca tiveram a oportunidade de fazê-lo. ${ }^{60}$ As autoridades venezuelanas lamentaram uma suposta falta de exaustão de instâncias nacionais. ${ }^{61}$ Além disso, declararam que no caso Usón Ramírez v. Venezuela, uma gravação das deliberações judiciais revelou que a Corte Interamericana de Direitos Humanos chegou ao seu julgamento "sem ouvir a defesa, as partes ou mesmo as respostas às suas próprias perguntas." 62

Ao contrário das declarações dos Comissários como investigadores e acusadores, as decisões da Comissão e da Corte vinculam o Estado. ${ }^{63}$ Como consequência, são bastante importantes para os governos envolvidos. É pertinente notar que Venezuela, Equador, Bolívia e Nicarágua - como virtualmente todos os outros países latino-americanos - originalmente não apenas ratificaram a Convenção Americana, mas também reconheceram a vinculatividade da jurisdição da Corte. ${ }^{64}$

Contudo, as queixas em torno de algumas decisões não constituem o centro do problema entre o Eixo Bolivariano e o Sistema Interamericano de Direitos Humanos. Normalmente justificariam uma moção de reconsideração, não um desafio à legitimidade do regime como um todo. Além do mais, participar de um esquema judicial implica, além de tentar dispor dos argumentos mais sólidos disponíveis na esperança de vencer a disputa, aceitar a possibilidade de derrota e de ter de cumprir apesar de talvez discordar do tribunal. Mesmo que as decisões discutidas indiquem um longo padrão de erro e injustiça, justificariam um pedido para mudança da constituição da Comissão e da Corte, mas não a reforma total do regime dos direitos humanos.

\footnotetext{
${ }^{60}$ Maduro Moros, Carta, supra nota 15, p. 4.

${ }^{61} I d$.

62 Id., p. 7.

${ }^{63}$ Ver, e.g., Convenção Americana, supra nota 14, art. 51(2) (“A Comissão fará as recomendações pertinentes e fixará um prazo dentro do qual o Estado deve tomar as medidas que lhe competirem para remediar a situação examinada.”); id. art. 68(1) (“Os Estados Partes na Convenção comprometem-se a cumprir a decisão da Corte em todo caso em que forem partes.").

${ }^{64}$ Ver supra nota 2, e texto subsequente.
} 
Ademais, os casos contestados somam uma minoria em meio aos casos abertos contra a Venezuela entre 2000 e $2012 .{ }^{65}$ Mais precisamente, formam um por cento (1\%) do total. De toda forma, o requerente venceu em somente (3\%) das ações abertas contra o Estado venezuelano durante esse período. ${ }^{66}$ Tais números mostram que, sem ser novidade, as autoridades possuem circunstâncias mais favoráveis do que os peticionários nesses procedimentos.

Obviamente, todos os membros da Organização dos Estados Americanos têm esporadicamente confrontado determinações desfavoráveis. ${ }^{67}$ Alguns têm subsequentemente demonstrado desapontamento ou até indignação. Por exemplo, "o Brasil . . . retirou seu embaixador junto à Organização em 2011 após o pedido oficial da Comissão para suspender a construção da hidrelétrica de Belo Monte" com o objetivo de proteger os direitos dos povos indígenas afetados. ${ }^{68} \mathrm{O}$ país se juntou à Argentina e Venezuela para criticar "muito duramente o trabalho da Comissão Interamericana de Direitos Humanos" durante "a sessão inaugural da Assembleia Geral" de 2012 da Organização. ${ }^{69}$

Apesar de não se identificar como bolivarianos, Brasil, Argentina e Guatemala têm dado suporte ao pedido geral para renovação. ${ }^{70}$ No entanto, têm mantido sua adesão ao Sistema Interamericano de Direitos Humanos. Não têm realizado um ataque ostensivo baseados nas suas discordâncias com algumas poucas decisões.

De qualquer maneira, as postulações venezuelanas nos precedentes listados na Denúncia e na Fundamentação não são particularmente emocionantes ou convincentes. No contexto da sua principal reclamação, a Venezuela nunca se importou em reconhecer a existência de exceções ao requerimento de exaustão de instâncias nacionais, ${ }^{71}$ deixando de explicar por que

\footnotetext{
${ }^{65}$ Para os propósitos deste artigo, Lauren Kinell conduziu, como pesquisadora assistente, uma rápida pesquisa nos sites da Comissão e da Corte e concluiu que ambos os órgãos decidiram favoravelmente no mérito nos pedidos dois (2) e quatorze (14), respectivamente, de um total de 573 petições protocoladas entre 2000 e 2012.

${ }^{66} I d$.

${ }^{67}$ Ver em geral Cms. Inter-Am. D.H., Rel. Anual 2010, supra nota 53.

${ }^{68}$ Eva Sáiz, La OEA, dividida ante la reforma de su órgano de derechos humanos, El PAís (7 de dez. de 2012).

${ }^{69} \mathrm{Id}$.

${ }^{70} \mathrm{Id}$.

${ }^{71}$ Por exemplo, a Convenção Americana de Direitos Humanos estabeleceu que o requerimento não se aplica: quando (a) não existir, na legislação interna do Estado de que se tratar, o devido processo legal para a proteção do direito ou direitos que se alegue tenham sido violados; (b) não se houver permitido ao presumido prejudicado em seus direitos o acesso aos recursos da jurisdição interna, ou houver sido ele impedido de esgotá-los; e (c) houver demora injustificada na decisão sobre os mencionados recursos.

Convenção Americana, supra nota 14, art. 46(2).
} 
nenhuma delas se aplica. Na verdade, as instituições do Sistema Interamericano de Direitos Humanos tomaram uma abordagem relativamente padrão para a questão.

Em Usón Ramírez, por exemplo, a Corte citou seus próprios precedentes, assim como os da Corte Europeia de Direitos Humanos, sustentando que as autoridades haviam renunciado à defesa do esgotamento de recursos ao não levantar a questão durante a fase de admissibilidade. ${ }^{72}$ Além disso, decidiu contra o governo venezuelano em termos idênticos no caso Perozo. ${ }^{73}$ Por fim, os juízes concluíram, a respeito de uma das reivindicações em Díaz Peña, que a lei interna da Venezuela não oferecia nenhum remédio que o peticionário pudesse ter exaurido. ${ }^{74}$ No entanto, concordaram com o Estado venezuelano a respeito de outras acusações presentes no mesmo processo. ${ }^{75}$

A Comissão Interamericana, por sua vez, procedeu nos casos citados de forma análoga. Baseou-se na demora injustificada no iniciado processo doméstico com o objetivo de isentar o peticionário de exaurir as instâncias existentes para o caso López Mendoza. ${ }^{76}$ Em Brewer Carías, os Comissários invocaram a mesma razão para a exceção, assim como acesso precário do pleiteante aos remédios disponíveis. ${ }^{77}$

Certamente, a alegação de prejulgamento em Usón Ramírez poderia ter mais peso. No entanto, ela não requer nenhuma análise jurisprudencial profunda, pelo contrário, apenas uma análise cuidadosa da prova disponível. O que os magistrados disseram exatamente na gravação antes da argumentação oral? Simplesmente insinuaram uma inclinação para votar contra a Venezuela baseados nas submissões escritas? Ou realmente demonstraram que tinham definitivamente tomado uma posição e não pensavam encarar a disputa entre as partes de forma séria?

Estranhamente, as autoridades venezuelanas parecem não ter abordado a matéria durante o litígio. Aparentemente, o fizeram apenas três anos depois quando denunciaram da

\footnotetext{
${ }^{72}$ Usón Ramírez vs. Venezuela, Ct. Inter-Am. D.H. (Ser. C) No. 207 (20 de novembro de 2009), pp. 6-7 (III 1923).

${ }^{73}$ Perozo vs. Venezuela, Ct. Inter-Am. D.H. (Ser. C) No. 195 (28 de janeiro de 2009), p. 14 (II 44).

${ }^{74}$ Díaz Peña vs. Venezuela, Ct. Inter-Am. D.H. (Ser. C) No. 244 (26 de jun. de 2012), p. 49 (đI126).

${ }^{75}$ Id., p. 48 (IIII 122-125).

${ }^{76}$ López Mendoza vs. Venezuela, Pet. 275-08, Cms. Inter-Am. D.H., Rel. No. 67/08, OEA/Ser. L/V/II.134, doc. 5 rev. 1 (25 de julho de 2008), p. 7 (II 34).

${ }^{77}$ Brewer Carías vs. Venezuela, Pet. 84-07, Cms. Inter-Am. D.H., Rel. No. 97/09, OEA/Ser. L/V/II, doc. 51 corr. 1 (8 de set. de 2009), p. 17 (IIII 87, 89), 17 (IIII 95-96).
} 
Convenção Americana. Todavia, o não expuseram sua acusação à contestação da parte adversa ou à análise judicial.

Além disso, a Venezuela não identificou nenhum erro substancial que os juízes pudessem ter cometido. O requerente e o tribunal poderiam ter argumentado de forma convincente a citada violação procedimental como inócua. Em qualquer caso, os documentos denunciativos da Venezuela nunca entraram no problema do exaurimento de instâncias em Usón Ramírez.

Em suma, interpretar a reclamação bolivariana como baseada principalmente nessas decisões desfavoráveis resultaria numa distorção e na privação da questão de substancial interesse. A insatisfação manifestada pelas autoridades venezuelanas não se diferencia muito da realizada por outros países sob circunstâncias similares. Tipicamente motivaria apenas uma moção de reexame, uma nota oficial de protesto ou, em circunstâncias extremas, um pedido de renúncia dos membros dos órgãos competentes.

De forma significativa, a argumentação levantada não contribuiria muito para a atual discussão internacional sobre direitos humanos. Primeiro, o argumento em torno ao exaurimento de instâncias não parece persuasivo. E segundo, a posterior alegação de que os juízes nunca ouviram os argumentos das partes carece de desenvolvimento e se refere a uma única disputa.

\section{POLITIZAÇÃo}

$\mathrm{Na}$ verdade, o bloco bolivariano provavelmente está advogando pela politização dos direitos humanos. Deve estar argumentando, em outras palavras, que o Sistema Interamericano de Direitos Humanos necessita reconhecer e focar nas políticas de tais direitos. Assim, os órgãos investigativos e acusatórios deveriam apoiar, ao invés de minar, a cruzada de países como Venezuela, Equador, Bolívia e Nicarágua em favor dos valores políticos e das políticas implícitas na Convenção Americana.

É significativo que as nações dissidentes têm formulado seus protestos majoritariamente em espanhol, que, como o português, tem apenas uma palavra, 'política', para denominar tanto 
'politics' quanto 'policy' da língua inglesa. ${ }^{78}$ De fato, outros idiomas também têm um único termo para ambos: e.g., 'politique' em francês, 'Politik' em alemão. ${ }^{79}$ Portanto, um falante de qualquer uma dessas línguas poderia rapidamente associar os dois conceitos. Além disso, provavelmente entenderia a politização dos direitos humanos como uma realização destes através de uma série de políticas concretas.

De qualquer forma, a reivindicação dos dissidentes incide em três pontos independentes, embora interligados. Primeiro, os Estados têm impulsado tais direitos como uma parte do seu próprio engajamento político e, portanto, o Sistema Interamericano de Direitos Humanos deve respeito à interpretação estatal. Segundo, os direitos humanos geralmente envolvem política e, como resultado, o governo merece deferência devido à sua legitimidade democrática e especialização nesse âmbito. E, terceiro, os juízes devem refletir antes de punir nações que têm se dedicado politicamente aos ideais emancipatórios que sustentam tais direitos.

Dessa perspectiva, a Comissão e a Corte têm feito exatamente o oposto do que deveriam fazer, em todos os três pontos. Têm se negado a deferir aos Estados, sejam como signatários de tratados relevantes, de forma estrita, ou como unidades governamentais, de forma ampla. Além disso, têm se recusado a apreciar a extensão na qual regimes de esquerda têm se destacado em propulsar politicamente direitos como igualdade, dignidade, saúde, moradia e diversidade cultural.

Supostamente, têm violado ou manipulado regras com o intuito de atacar um projeto político progressista e cooperado com forças imperialistas. Têm invertido a hierarquia dos direitos humanos em detrimento dos direitos programáticos carregados politicamente. Em particular, têm colocado a liberdade de expressão em primeiro lugar e os direitos sociais, econômicos e culturais em último.

Como na formulação anterior, alguém pode se perguntar por que a solução não consistiria simplesmente em sancionar ou substituir os membros dos órgãos de efetivação. Em resposta, as nações descontentes identificariam um problema mais pervasivo. Alegariam que a

\footnotetext{
${ }^{78}$ Ver verbete para "policy" (1(a \& b)), English-Spanish THE OXFORD SPANISH DictionARY 1438 (1994) (traduzindo "policy" como "política."); verbete para "policy," English-Portuguese, HIPPOCRENE PORTUGUESEENGLiSh English-Portuguese Dictionary 275 (Rev. ed. 1991) (traduzindo "policy" como "política").

${ }^{79}$ Ver verbete para "policy" (1), English-French, HARRAP's FRENCH DICTIONARY 640 (1991) (traduzindo "policy" como "politique."); verbete para "policy" (1(a \& b)), English-German, HARPER COLLINS GERMAN DICTIONARY 512 (2d ed. 1991) (traduzindo "policy" como "Politik.").
} 
Organização dos Estados Americanos, sob a influência perversa dos Estados Unidos, não tem nenhum interesse em direitos humanos, e muito menos no progressismo. Em razão disso, impõe uma agenda conservadora que desvirtua qualquer tentativa de renovar as entidades criticadas ou até mesmo substituir seu pessoal.

A Venezuela de forma inequívoca enuncia essa questão na sua Denúncia: "Nada adiantaram os esforços dos Estados membros da Organização dos Estados Americanos para promover a necessária reforma e modificação de ambas as instituições. Estas se acham sequestradas por um pequeno grupo de burocratas inescrupulosos que têm bloqueado, obstaculizado e impedido as transformações necessárias." ${ }^{80} \mathrm{Na}$ Fundamentação, as autoridades venezuelanas reclamam, mais precisamente, que o governo dos Estados Unidos, mostrando "o maior descaro", que merece o "mais forte e categórico repúdio", "impossibilita modificar ou corrigir o . . . Sistema." ${ }^{\prime 1}$

Desse ponto de vista, o "império" provavelmente não está apenas tentando se agarrar aos seus indicados para a burocracia dos órgãos e evitar qualquer tentativa de reduzir a incidência de erro e enviesamento nas suas investigações e decisões. Mais que isso, está procurando evitar uma derrota na sua batalha política transcontinental contra forças anticoloniais ao Sul da sua fronteira. Em razão disso, a Comissão e a Corte deveriam (mas provavelmente não irão) deferir aos Estados revolucionários como partes do tratado e como governos. Deveriam abraçar uma política iluminada, uma visão dos direitos humanos contrária à estado-unidense. Como observado pela Venezuela, "os Estados Unidos não ratificaram a Convenção Americana de Direitos Humanos" 82 e, consequentemente, devem gozar de menos influência, independentemente da sua alegada inclinação reacionária.

De fato, o grupo bolivariano nunca articulou explicitamente sua reivindicação de forma elaborada. No entanto, tem claramente condenado a Comissão e a Corte por não se subordinarem suficientemente aos Estados signatários ou aos governos em geral, principalmente àqueles mais comprometidos com a emancipação da sociedade. Também tem as depreciado como excessivamente centradas na liberdade de expressão, em detrimento dos

\footnotetext{
${ }^{80}$ Maduro Moros, Carta, supra nota 15, p. 2.

${ }^{81}$ Maduro Moros, Fundamentación, supra nota 15, p. 5-6.

${ }^{82}$ Id., p. 6.
} 
direitos sociais. Como um todo, as objeções realizadas buscam uma interpretação politicamente correta da Convenção Americana.

Por exemplo, o Embaixador da Venezuela à Organização dos Estados Americanos acusou a Comissão Interamericana de Direitos Humanos de ser uma fronte para uma "máfia" que opera como "uma inquisição especial contra governos de esquerda." 83 Ele estava reproduzindo uma declaração anterior do antigo Presidente Hugo Chávez: "Existe uma máfia ali. A última coisa que instituições como a nefasta Comissão Interamericana de Direitos Humanos fazem é defender direitos humanos. É um órgão politizado, utilizado pelo império para agredir governos como o da Venezuela." ${ }^{84}$

Por sua vez, o Presidente boliviano, Evo Morales, tem afirmado que a enviesada Organização das Nações Unidas “tem encoberto ditaduras e intervindo em nações" e "permitido a repressão e o escarmento de movimentos sociais". ${ }^{85}$ Morales tem feito campanha aberta para a "dissolução de vários órgãos" 86 de "dominação e submissão" 87 . Ameaçando retirar seu país do Sistema Interamericano de Direitos Humanos, ele comparou a Comissão a uma "base militar dos Estados Unidos." 88

O jornal espanhol El país tem ostensivamente feito a cobertura do debate acerca da liberdade de expressão. "O Eixo Bolivariano" tem acusado "a comissão para a liberdade de expressão da Comissão Interamericana de Direitos Humanos de refletir a hegemonia de meios de comunicação que não praticam 'liberdade de expressão, mas de extorsão." 89 De acordo com a aliança, esse “exercício de poder . . . permite uma 'ditadura da mídia' contra governos progressistas da região." 90

\footnotetext{
${ }^{83}$ Eva Sáiz, La OEA, dividida ante la reforma de su órgano de derechos humanos, El PAís (7 de dez. de 2012) (citando o Embaixador da Venezuela à Organização dos Estados Americanos).

${ }^{84}$ Maye Primera, Chávez ordena la salida de Venezuela de la CIDH, El PAís (26 de fev. de 2010) (citando o presidente venezuelano Hugo Chávez).

${ }_{85}$ Mabel Azcui, Evo Morales: "La OEA puede morir al servicio del imperio o renacer," El PAís (4 de jun. de 2012) (citando o presidente boliviano Evo Morales).

${ }^{86} I d$.

${ }^{87} I d$. (citando o presidente boliviano Evo Morales).

${ }^{88}$ Eva Sáiz, El ALBA afronta aislado la reforma del sistema de derechos humanos de la OEA, EL PAís (21 de mar. de 2013) (citando o presidente boliviano Evo Morales).

${ }^{89}$ Mabel Azcui, El eje bolivariano ataca la Comisión Interamericana de Derechos Humanos, El PAís (6 de jun. de 2012) (citando o "Eixo Bolivariano").

${ }^{90} I d$.
} 
Como mencionado na Introdução, uma das propostas de reforma do Equador consiste em impedir que "terceiros Estados" ou "outras instituições" façam contribuições financeiras com um "fím específico". ${ }^{91}$ Ela comprometeria seriamente as finanças da Comissão e teria efetivamente "acabado com o Relatoria de Liberdade de Expressão."92 "Essa Relatoria, sendo especial, é a única que não é financiada com fundos da Organização dos Estados Americanos e que depende inteiramente de programas de cooperação internacional." 93 De fato: "Essa circunstância significa que seu orçamento triplica o do resto das relatorias." "94 Contra esse estado de coisas, as autoridades equatorianas propuseram corrigir, sem demora, "o desequilíbrio de recursos econômicos e humanos disponíveis [às diferentes] relatorias."95

Ao denunciar, o governo venezuelano similarmente expressou seu compromisso "com a equilibrada realização dos direitos econômicos, sociais, culturais, civis e políticos." 96 Ainda, apontou que ele daria igual peso a direitos positivos e negativos, incluindo a liberdade de expressão. Tipicamente, estes últimos obrigam ao Estado a tomar, e aqueles a desistir de, um certo curso de ação.

As autoridades do Equador também defenderam essa posição na sua proposta. Urgiram para que o Capítulo IV do Relatório Anual da Comissão "se concentre não apenas nos direitos civis e políticos, mas também nos econômicos, sociais e culturais."97 Desse prisma, os juízes interamericanos deveriam se abster de impor seu conservadorismo ideológico ao sopesar todos esses direitos e de alienar os regimes não afins.

O Presidente boliviano, Evo Morales, tem frequentemente focado em direitos relacionados ao bem coletivo. Por exemplo, tem insistido em que "todos os povos da América Latina devem disfrutar de acesso a todos os serviços básicos - como energia, água e

\footnotetext{
${ }^{91}$ Eva Sáiz, La OEA cierra en falso la reforma del su sistema de derechos humanos, EL PAís (23 de mar. de 2013). Ver Propuestas de la Delegación del Ecuador, supra nota 11Erro! Indicador não definido. (As "contribuições voluntárias não deveriam ser "condicionadas ou direcionadas.") Ver também Eva Sáiz, La OEA, dividida ante la reforma de su órgano de derechos humanos, EL PAís (7 de dez. de 2012).

${ }^{92}$ Eva Sáiz, La OEA cierra en falso la reforma del su sistema de derechos humanos, EL PAís (23 de mar. de 2013).

${ }^{93} I d$.

${ }^{94}$ Id. Ver também Eva Sáiz, El ALBA afronta aislado la reforma del sistema de derechos humanos de la OEA, EL PAÍs (21 de mar. de 2013).

95 Propuestas de la Delegación del Ecuador, supra nota 11.

${ }^{96}$ Maduro Moros, Carta, supra nota 15, p. 10.

${ }^{97}$ Propuestas de la Delegación del Ecuador, supra nota 11.
} 
telecomunicações - como um direito humano." ${ }^{98}$ Ele também tem falado sobre uma "obrigação de quebrar o monopólio dos medicamentos." 99

Curiosamente, a Nota Denunciativa da Venezuela acusa a Comissão e a Corte de agirem politicamente, reprovando-as por "terem se convertido numa arma de arremesso política." $100 \mathrm{O}$ documento refere aos "casos" analisados como "claramente politizados e parcializados contra o Estado venezuelano." ${ }^{101}$ Evoca, ainda, a citação anterior do Presidente Chávez descrevendo a Comissão Interamericana de Direito Humanos como "um órgão politizado, utilizado pelo império para agredir governos como o da Venezuela."102

Obviamente, tal linguagem sugere que os representantes venezuelanos percebem a politização dos direitos humanos como um problema. No entanto, pode indicar que as autoridades da Venezuela são contrárias à politização destes de um modo específico. A Venezuela pode estar atacando a Comissão e a Corte em razão de estarem incentivando um modo equivocado de política - viz., contrarrevolucionário e não democrático - nas suas tomadas de decisão.

Quase todos os governos em questão têm lidado com a implementação de direitos internamente de maneira semelhante, o que joga uma luz sobre a sua intenção no exterior. Eles têm (1) de início, atacado o Judiciário nacional por possuir um papel destrutivo e não de apoio aos seus programas políticos; (2) em seguida, mudado a composição das suas principais cortes constitucionais; (3) consequentemente, instituído novas Constituições que refletem suas convicções progressistas; e, (4) finalmente, lutado para manter os novos juízes investidos em linha politicamente. ${ }^{103} \mathrm{Na}$ Venezuela, Equador e Bolívia, as autoridades têm evidentemente atuado seguindo o mesmo roteiro em torno à politização de direitos e de instituições jurídicas.

\footnotetext{
${ }^{98}$ Mabel Azcui, El presidente Correa dice que la OEA debe “revolucionarse o desaparecer,” EL PAÍs (5 de jun. de 2012) (citando o presidente boliviano Evo Morales).

${ }^{99}$ Id.

${ }^{100}$ Maduro Moros, Carta, supra nota 15, p. 2.

${ }^{101}$ Id., p. 4.

102 Maye Primera, Chávez ordena la salida de Venezuela de la CIDH, EL PAÍs (26 de fev. de 2010) (citando o presidente venezuelano Hugo Chávez).

${ }^{103}$ Ver OQUENDO, supra nota 2, p. 170-195 (Ch. III, § E) ("When Constitutionalism Breaks Down: Venezuela's 1999 Constitutional Crisis"). Sobre a situação no Equador, ver EFE, El Parlamento de Ecuador designa un nuevo Tribunal Constitucional tras el cese del anterior, EL PAÍs (1 de jun. de 2007); Daniela Creamer, Correa celebra un referéndum que le permitirá controlar la justicia, EL PAÍs (7 de maio de 2011). Sobre a situação na Bolivia, ver Mabel Azcui, Morales emprende la reforma del poder judicial con 18 nombramientos, EL PAís (19 de fev. de 2010).
} 
Esses regimes têm certamente a intenção de continuar sua campanha política na arena internacional. Já deram o primeiro passo atacando os principais órgãos do Sistema Interamericano de Direitos Humanos e mantendo um pedido geral de troca dos atuais juízes. ${ }^{104}$ Talvez não sintam nenhuma necessidade, no momento, de começar uma complicada tarefa de alteração das normas convencionais da região porque os amplos direitos em questão se encaixam bem em suas próprias políticas. No entanto, provavelmente sonham em introduzir uma entidade investigativa e decisória que concorde com sua agenda ou, ao menos, que não interfira nela.

Com certeza, o repúdio ao escrutínio judicial nacional e internacional poderia parecer repousar, mais uma vez, no desejo de obter a supremacia soberana absoluta. O antigo Embaixador do Panamá para a Organização dos Estados Americanos, Guillermo A. Cochez, arrisca uma tal interpretação. Referindo-se principalmente a Venezuela, Equador, Bolívia e Nicarágua, ele escreve: “A justiça tem se tornado o calcanhar de Aquiles de aqueles que não desejam nenhum controle sobre eles e que entendem o poder como uma maneira de fazer praticamente o que quiserem."105

Independente dos méritos dessa acusação, as nações dissidentes parecem principalmente estar colocando em prática sua concepção política dos direitos humanos. Dessa ótica, as cortes devem sustentar a visão oficial do programa político. Naturalmente, não devem lealdade ao governo, como um membro de ministério. No entanto, o Judiciário deve se conformar pelo bem da congruência e integridade.

Nesse sentido, os tribunais agem incongruentemente quando assumem um viés político e avançam suas políticas preferenciais. Especificamente, expõem a sociedade à uma desordem política. A situação se assemelha de algum modo à de um país no qual o presidente e o primeiroministro pertencem a partidos diferentes, como ocasionalmente acontecia na França anteriormente ao referendo de 2000, que trouxe uma emenda à Constituição francesa para tornar

\footnotetext{
${ }^{104}$ Ver em geral Introdução, supra.

105 Guillermo A. Cochez, La justicia y el poder, EL PAís (31 de agosto de 2013).
} 
esse cenário improvável. ${ }^{106}$ Um Judiciário ativista pode provocar tanto dano quanto um segundo chefe de governo "trabalho contra a corrente"107 do Poder Executivo.

Ainda, as cortes atropelam a integridade da ordem legal quando suplantam autoridades eleitas. Além do mais, violam os princípios essenciais da sua profissão. Ao contrário do primeiro ministro, os juízes normalmente carregam um dever de restrição e devem se abster de envolvimento em política.

De qualquer forma, a demanda descrita soa provocativa exatamente porque encara os direitos humanos de forma política, assim como porque limita severamente os tribunais nacionais e internacionais. Ao mesmo tempo, parece contrariar a intuição. Se tende a pensar em tais direitos como opostos ou pelo menos distintos da política.

A asserção sob análise incita a um otimismo revolucionário sobre a capacidade do Estado de honrar tanto os direitos humanos como a política. Renova radicalmente a exigência, que grupos estadunidenses de esquerda e de direita pronunciaram no passado, ${ }^{108}$ de conceder aos poderes políticos significativa margem de manobra nos seus domínios. A novidade reside na ideia de que instituições judiciais devem se submeter porque lidam não com políticas (ao contrário de direitos), mas com direitos inevitavelmente políticos.

Como notado, o Eixo Bolivariano não apresentou suas postulações nesses termos. No entanto, ele fez afirmações que combinam com a formulação elaborada nesta seção. Além disso, a presente construção torna a reivindicação mais interessante para uma discussão internacional e acadêmica sobre direitos humanos. A Parte II reforçará ainda mais esta afirmação.

\footnotetext{
${ }^{106}$ Ver Suzanne Daley, In Underwhelming Turnout, French Voters Cut Presidential Term, N.Y. TiMES (25 de set. de 2000), p. A3 ("Um referendo para diminuir o mandato do Presidente da França de sete para cinco anos foi amplamente aprovado hoje por meio de um número recorde de votantes que não se se fez presente às urnas. ... . Apoiadores têm argumentado que o mandato de sete anos irá diminuir ou eliminar estranhos períodos de 'coabitação' como o que a França tem experienciado agora com um presidente e primeiro-ministro de diferentes partidos e geralmente em desacordo sobre questões cruciais").

${ }^{107} I d$.

${ }^{108}$ Ver, e.g., Duncan M. Kennedy, The Critique of Rights in Critical Legal Studies, in LeFT Legalism/LefT CRITIQUE 178, 199-200 (Janet Halley \& Wendy Brown eds., 2002) ("Os realistas argumentavam [nas décadas de 20 e 30] que em razão de o tradicional caso dos direitos constitucionais contra a estatutos de reforma envolver meramente argumentos de política, as cortes tiveram especificamente nenhuma base legal para anular julgamentos legislativos ... moderados e conservadores afirmaram [em 1950] que em razão de tudo o que uma corte poderia fazer seria balancear direitos contra poderes ou direitos entre si, eles tiveram nenhuma base legal para anular decisões legislativas.").
} 


\title{
3. ANÁLISE DA REIVINDICAÇÃO
}

\section{A. PRINCÍPIOS}

Encontrando inspiração nos escritos de Immanuel Kant, muitos filósofos contemporâneos têm concebido os direitos humanos como apolíticos. Em outras palavras, eles têm buscado demonstrar que tais direitos não formam parte do reino da política. A reivindicação bolivariana, como definida, colide diretamente com essa intrincada visão dos direitos humanos.

Jürgen Habermas, no entanto, decididamente divide a esfera moral e a ética-política e coloca os direitos fundamentais na primeira delas. A moral interessa aos indivíduos em qualquer lugar e de forma semelhante: "Pela pergunta de questões morais, a humanidade - ou uma presumida república de cidadãos globais - constitui o sistema de referência para a justificação de regulações que interessam igualmente a todos. As conclusões devem, em princípio, ser capazes de serem aceitas por todo mundo." ${ }^{109}$ Matérias ético-políticas, contudo, referem-se somente a uma comunidade particular:

\begin{abstract}
Ao abordar questões ético-políticas, a forma de vida das "nossas respectivas" coletividades políticas constitui o sistema de referência para a justificação de regulações que expressam um consciente e coletivo autoconhecimento. As conclusões devem, em princípio, ser capazes de serem aceitas por todos os membros que dividam "nossas" tradições e mais firmes valores. ${ }^{110}$
\end{abstract}

Enquanto a moralidade é deontológica, a política ética é teleológica. Dessa forma, a primeira impõe obrigações independentemente dos propósitos do agente; a última é vinculante desde o momento em que o agente adota um fim específico ou telos. ${ }^{111}$

Além disso, as razões morais possuem prioridade hierárquica e prevalecem sobre as suas contrapartidas políticas. Sustentam princípios ou normas como opostos a valores. É significativo que os princípios não devam chocar-se entre si, mas, ao invés disso, devam

\footnotetext{
109 JÜRgEn HABERMAS, FAKTIZITÄT UND GELTUNG: BEITRÄGE ZUR DISKURSTHEORIE DES RECHTS UND DES DEMOKRATISCHEN RECHTSSTAATS 139 (1992) [daqui em diante, HABERMAS, FG].

${ }^{110}$ HABERMAS, FG, supra nota 109, p. 139. Ver também JÜRGEN HABERMAS, DIE EINBEZIEHUNG DES ANDEREN: STUDIEN ZUR POLITISCHEN THEORIE 252 \& 254 (1996) [daqui em diante, HABERMAS, EA].

${ }^{111}$ HABERMAS, FG, supra nota 109, p. 127, 188.
} 
constituir um sistema coerente. Valores, por sua vez, geralmente competem entre si e permitem um ranqueamento de acordo com a medida em que os sujeitos se aderem a eles. ${ }^{112}$

Ronald Dworkin faz outra articulação dessa posição geral. Ele diferencia entre princípios e política nos seguintes termos:

Eu chamo política pública aquele tipo de conduta que estabelece um objetivo a ser alcançado, geralmente uma melhoria em alguma característica econômica, política ou social da comunidade (embora algumas metas sejam negativas por estipularem que alguma característica presente deve ser protegida de uma mudança adversa). Chamo 'princípio' um padrão para ser observado não porque irá melhorar ou garantir uma situação econômica, política ou social considerada desejável, mas porque é um requisito de justiça ou alguma outra dimensão de moralidade. ${ }^{113}$

Por fim identifica os direitos fundamentais com princípio e moralidade, não com política pública. Ele expressamente descreve a interpretação de "direitos individuais" como "morais que não . . . políticos” e principalmente de prerrogativa do Judiciário. ${ }^{114}$

Dworkin e Habermas concordam que os direitos humanos básicos se apoiam em princípios e pertencem ao reino da moralidade ao invés da política pública. Ambos acreditam que esse tipo de direito é vinculante e tem precedência sobre ideais políticos.

Como esperado, outros filósofos, especialmente aqueles que operam sob influência de Kant, abraçam essa perspectiva. Tim Scanlon exemplifica essa tendência:

Isto quer dizer, primeiro, que afirmar um direito não é meramente estabelecer o valor de algum objetivo ou o grande prejuízo de um certo dano acontecer. Pelo contrário, é negar que governos ou indivíduos tenham a autoridade para agir de certa forma ou afirmar que eles têm um dever afirmativo de agir de certo modo, por exemplo, prestar assistência de maneira específica. ${ }^{115}$

Nessa passagem, Scanlon da mesma forma opõe direitos a objetivos e valores e os associa com obrigações, assim como com limites ao poder político das autoridades.

\footnotetext{
${ }^{112}$ Ver em geral Ángel R. Oquendo, When Democracy and Human Rights Collide, 7 SYMP. 67 (2003).

113 Ronald DWORKIN, TAKING Rights SERIOUSLY 22 (1977) [daqui em diante, DwORKIN, Rights]. Ver também RONALD DWORKIN, A MATTER OF PRINCIPLE 72-103 (1985).

${ }^{114}$ Ronald Dworkin, Constitutionalism and Democracy, 3 EUR. J. PHIL. 2, 10-11 (1995); ver em geral Ronald Dworkin, Rights as Trumps, in THEORIES OF RIGHTS 153 (Jeremy Waldron ed., 1984).

115 ThOMAs M. SCANLON, Human Rights as a Neutral Concern, in THE DifFICUlTy OF TOLERANCE: ESSAYS IN POLITICAL PHILOSOPHY 113, 115 (2003). Ver também id., p. 117 ("Mesmo aqueles direitos humanos que envolvem o menor comprometimento com remédios institucionais específicos retêm um caráter politico que os diferenciam de meras metas.").
} 
Mesmo alguns dos atuais inimigos dessa bem arraigada concepção dos direitos humanos parecem concordar, se apoiando na filosofia de Aristóteles, Hegel, Marx ou Nietzsche, com essa definição. Por exemplo, Richard Rorty, invocando os escritos de Eduardo Rabossi, rejeita tais direitos justamente porque se baseiam em princípios que parecem derivar de uma razão universal aplicável a todos os seres racionais. ${ }^{116} \mathrm{O}$ "problema com o discurso dos direitos", ele diz, "é que entende a moralidade política não como um resultado do discurso politico - da reflexão, transigência e da escolha do mal menor - mas de um imperativo moral incondicional. ${ }^{117}$ Rorty segue a opinião de Annette Baier na sua distanciação dos direitos humanos em prol de um entendimento baseado na simpatia, confiança, sentimentos, cuidado e solidariedade. $^{118}$

Bernard Williams, por sua vez, censura as tentativas de expandir a noção de direitos humanos além de uma estreita noção de "coerção não mediada"119, construída contextualmente, às "boas coisas" em geral, tais quais "os chamados direitos positivos, como o direito ao trabalho." ${ }^{120}$ Explica que "existem bens humanos cujo valor talvez não seja melhor expresso em termos de direitos." $" 121$ Ainda, diferencia os direitos do que é bom e de valores, mais amplamente.

Além disso, distingue direitos humanos de políticas públicas. Por exemplo, censura os liberais estadunidenses que advogam, sob a Primeira Emenda da Constituição, a proteção do discurso de ódio. Sugere que desse modo articulam uma "forte convicção pessoal”, que se refere a uma "questão de política pública", ao invés de "[a um] assunto unicamente de direitos". ${ }^{122}$

\footnotetext{
${ }^{116}$ Ver Richard Rorty, Human Rights, Rationality and Sentimentality, em THE POLITICS OF HUMAN RIGHTS 67-83 (Belgrade Circle ed., 1999) Rorty afirma que:

A alegação de Rabossi de que o fundamentalismo dos direitos humanos está ultrapassado me parece tanto verdadeira quanto importante; elas serão meu principal tópico neste ensaio. Vou desenvolver e defender a afirmação de Rabossi, de que não vale a pena discutir se os seres humanos têm realmente os direitos enumerados na Declaração de Helsinki. Em particular, vou defender o argumento de que nada relevante à escolha moral separa seres humanos de animais a não ser os fatos históricos contingentes do mundo, fatos culturais.

$I d .$, p. 69-70.

${ }^{117}$ Richard Rorty, What's Wrong with “Rights," HARPER's, June 1996, p. 15.

118 Id à15-18.

119 Bernard Williams, Human Rights: The Challenge of Relativism 13, SACKLER DisTingUiSHED LeCTURE: UNIV. ConN. (23 de abr. de 1997).

${ }^{120} I d$., p. 2-3.

${ }^{121} I d$., p. 3.

${ }^{122} I d$., p. 5.
} 
Em suma, os filósofos citados iriam repudiar qualquer tentativa de politização dos direitos humanos. Iriam fazê-lo por diferentes motivos, mas convergiriam numa visão de que a identificação de tais direitos com um projeto político particular seria problemática. Não importando se os direitos deveriam prevalecer ordinariamente sobre a política, o establishment filosófico parece franzir o cenho perante a união dos primeiros com a última.

Desse ponto de vista geral, uma reivindicação baseada em direitos humanos constitui uma questão de princípio. Analisar se uma violação ocorreu envolve descobrir se o alegado violador quebrou a norma moral em jogo. Não tem nada a ver com política, seja a dos que tem redigido textualmente o direito em questão, a das entidades politicamente legítimas e competentes ou a das partes particularmente progressistas na disputa.

Por exemplo, um cidadão pode acusar às autoridades de estar violando a liberdade de expressão dele. A instituição adjudicante deve determinar deontologicamente se a violação do princípio subjacente ocorreu e, caso positivo, decidir a favor do requerente. Não deve ter em conta se o governo participou na elaboração da norma que estabelece o direito em exame, se tem alguma experiência específica ou legitimidade política, ou se agiu inspirado por um fim político maior.

No entanto, o regime pode reagir da maneira defensiva usual e insistir que limitou as liberdades de expressão da requerente porque estava, por exemplo, trabalhando para enfraquecer um programa - eticamente impecável - para redistribuição de terras. Ainda poderia tentar demonstrar que permitir a manifestação de pessoas assim poderia causar um dano inimaginável à população. Como resposta, contudo, o juiz poderia simplesmente citar John Rawls: "Cada pessoa possui uma inviolabilidade fundada na justiça, de que até mesmo o bemestar da sociedade como um todo não pode se sobrepor. . . . Assim, numa sociedade justa . . . os direitos garantidos pela justiça não estão sujeitos à barganha política ou a cálculo de interesse social."123

Não é surpresa que Ronald Dworkin assuma uma posição similar: "Um direito contra o governo deve ser um direito a se fazer algo mesmo quando a maioria pensar que isso seria ruim

${ }^{123}$ JOHN RAWLS, A THEORY OF JUSTICE 3-4 (1971). 
e até mesmo quando realizá-lo ameaçasse a maioria."124 "Se alguém tem direito a fazer algo," elucida, "então é errado que o governo o negue mesmo que faça baseado no interesse geral."125

Nem é preciso dizer que essa resposta geral depende de uma clara diferenciação entre, de um lado, normas e princípios, que subjazem os direitos, e, do outro, valores, que servem como base para política e políticas públicas. Habermas tenta meticulosamente definir e distinguir essas duas noções primordiais:

\begin{abstract}
Normas e valores diferem, primeiro, em que as primeiras se referem à ação obrigatória enquanto que os últimos se referem à ação teleológica; segundo, em que a validade da reivindicação das primeiras tem um sentido binário, enquanto a dos últimos tem um sentido gradativo; terceiro, em que as primeiras vinculam absolutamente e os últimos relativamente; e, quarto, em que a interligação de um sistema de normas e um sistema de valores deve satisfazer critérios diferentes. ${ }^{126}$
\end{abstract}

$\mathrm{Na}$ medida em que considera os direitos humanos essencialmente como normas, Habermas lhes atribui essas quatro propriedades.

Primeiro, tais direitos devem ser deontológicos - i.e., devem estabelecer um dever sem qualquer ligação a um fim particular. E mais, divergem da estrutura de políticas públicas teleológicas. Por exemplo, os direitos votar exigem eleições regulares não para aumentar a felicidade ou utilidade, mas para efetivar uma obrigação específica governamental. Requererse-ia sufrágio universal mesmo que se fossem prejudicados alguns ou vários fins da cidadania.

Segundo, um direito humano, ao invés de uma política pública, rotula determinadas ações como certas ou erradas, não como recomendáveis até um ou outro ponto. Por exemplo, direitos de privacidade podem permitir ou condenar a escuta telefônica. Não a categorizam como muito, relativamente ou apenas louvável. Enfim, se diferenciam de objetivos políticos particulares, como o da chamada zero tolerância ao crime.

Terceiro, Habermas acredita que o mandado dos direitos humanos básicos, como a dos princípios em geral, costuma "ter o sentido absoluto de uma incondicional e universal obrigação: duma reivindicação imperativa que é igualmente válida para todos." 27 Tais direitos, consequentemente, se aplicam a sociedades ao longo de todos os tempos. Esse caráter absoluto

\footnotetext{
${ }^{124}$ DWORKIN, RIGHTS, supra nota 113, p. 194.

${ }^{125} I d .$, p. 269.

${ }^{126}$ HABERMAS, FG, supra nota 109 , p. 311.

${ }^{127} I d$.
} 
não preclui a possibilidade de implantação contextual. Então os requisitos específicos podem variar de uma comunidade a outra. "A atratividade de valores," em contraste, "tem um sentido relativo de uma avaliação de bens que está incorporada ou adotada dentro de uma cultura ou forma de vida." 128 De forma consistente, Habermas define valores como sendo "preferências compartilhadas intersubjetivamente" 129 e atribui às políticas públicas, como uma subcategoria, a mesma denominação e reduzido escopo de aplicação.

Por fim, os vários direitos humanos devem formar um sistema coerente. Devem estar em harmonia entre si. Quando um deles prescreve um curso de ação, outro não deve direcionar em rumo contrário. Por exemplo, a liberdade religiosa, corretamente construída, deve sempre estar compatível com a igualdade sexual. No extremo oposto, objetivos políticos podem se chocar e competir entre si, necessitando de relativo ranqueamento. Por exemplo, encorajar a imigração de trabalhadores qualificados e atingir o pleno emprego entre a atual população podem, como políticas públicas, chocar e forçar um governo a equilibrá-las.

Dessa ótica, o grupo bolivariano parece estar engajado num erro de categoria. Especificamente, equivocadamente assimila direitos humanos a políticas públicas. No entanto, os primeiros, como normas, necessariamente divergem das últimas, como valores.

\section{B. POLÍTICAS}

A resposta descrita acima soa muito fácil, no entanto. Os aliados bolivarianos poderiam recalcar que a política pública forma uma parte essencial da aplicação de um direito. Poderiam utilizar direitos econômicos, sociais e culturais como exemplos.

Claro, a seção precedente já alude ao ceticismo de Bernard Williams vis-à-vis "os chamados direitos positivos, como o direito ao trabalho." ${ }^{130}$ Williams elabora:

Declarações de direitos humanos costumam defender direitos desse tipo, mas existe um problema com eles. Ninguém duvida que ter uma oportunidade de trabalhar é uma coisa boa, ou que desemprego é algo ruim. Mas significa isso que as pessoas têm direto a trabalhar? O problema é: contra quem se tem este direito? Quem o viola caso não seja observado? ... Mesmo que governos aceitem alguma responsabilidade pelos

\footnotetext{
${ }^{128} I d$.

${ }^{129} \mathrm{Id}$.

${ }^{130}$ Williams, supra nota 119 , pp. 2-3.
} 
níveis de desemprego, pode não ser possível para eles prover ou gerar trabalho, e, se eles falharem em fazê-lo, não fica claro que a melhor coisa a dizer é que o direito dos desempregados foi violado. ${ }^{131}$

Williams expressa assim uma preocupação comum na filosofia e no direito. Filósofos geralmente consideram esses direitos positivos como meras aspirações. ${ }^{132}$ Juristas frequentemente notam a falta de eficácia jurídica de tais direitos. ${ }^{133}$

Nessa conjuntura, os críticos do Sistema Interamericano de Direitos Humanos diriam, sem hesitação, que a Declaração Americana dos Direitos e Deveres do Homem contém o direito ao trabalho, assim como outros direitos positivos, ${ }^{134}$ e o Protocolo de San Salvador também. ${ }^{135}$ Destacariam ainda que a Convenção Americana de Direitos Humanos do mesmo modo contém um Capítulo sobre "Direitos Econômicos, Sociais e Culturais." "136 Além disso, os juízes nacionais e internacionais da região têm consistentemente reconhecido tais direitos como aplicáveis. $^{137}$

Inspirados por esses e outros documentos e decisões internacionais, os filosoficamente inclinados dificilmente podem questionar o reconhecimento internacional desse tipo de direito. No entanto, poderiam se manter céticos e argumentar que a razoabilidade impede que se reconheça tais direitos como genuínos. Bernard Williams indubitavelmente argumentaria assim.

De fato, considera "infeliz que declarações de direitos humanos têm, embora por motivos razoáveis, incluído os supostos direitos desse tipo."138 Acredita que a comunidade internacional, assim, mina o conceito de um direito humano:

Já que em vários casos os governos não podem realmente entregar aquilo ao que suas populações a priori têm direito, se encoraja a ideia de que direitos humanos representam simples aspirações, que eles assinalam bens e oportunidades que, sendo

\footnotetext{
${ }^{131} I d$.

${ }^{132}$ Ver id., p. 3 (“Já que vários casos de governo não podem realmente entregar o que as pessoas supostamente têm direito, isso encoraja a ideia de que direitos humanos representam simples aspirações. . . .”).

${ }^{133}$ Com tais direitos em mente, Joseph Raz observa que "direitos legais [nem] sempre são cogentes.” Joseph Raz, Rights and Politics, 71 IND. L.J. 27, 41 (1995). "Vários sistemas," ele afirma, "reconhecem o que pode ser chamado de direitos declaratórios, que não capacitam seus detentores a iniciar procedimento judicial para seu cumprimento. Eles podem ser meramente declaratórios, ou eles devem ser aplicados por outras instituições de governo. . . ." Id. ${ }^{134}$ American Declaration of the Rights and Duties of Man, art. XIV (May 2, 1948); Ver também id., arts. XI-XVI. 135 Protocolo de San Salvador (17 de nov. de 1988), art. 6. Ver também id., arts. 9-18.

${ }^{136}$ Convenção Americana, supra nota 14, ch. III ("Derechos Económicos, Sociales y Culturales").

${ }^{137}$ Ver OQUENDO, supra nota 2, pp. 351-386 (Ch. VI; § B).

${ }^{138}$ Williams, supra nota 119, p. 3.
} 
urgentes, deveriam ser providos se possível. Mas essa não é a essência de um direito. Se as pessoas têm direito a algo então alguém falha ao denegá-lo. ${ }^{139}$

Portanto, se concentra nas clássicas liberdades civis e políticas, ou num limitado, quase evidente, ${ }^{140}$ subconjunto, que se apoia na noção universal "de que poder não dá direito per se" e que o Estado age ilegitimamente quando exerce "poder coercivo não mediado". ${ }^{141}$

Alguém ainda poderia replicar, definindo direitos positivos de forma mais estrita. Os governos não têm uma vaga e ampla obrigação de criar empregos para os seus cidadãos. Pelo contrário, devem meramente demonstrar um sincero engajamento em prol do direito ao trabalho. Por exemplo, podem mostrar que têm implementado um programa confiável para alcançar o emprego pleno. Não precisam e não podem garantir sucesso nos seus empreendimentos.

Mesmo alguns filósofos influenciados por Immanuel Kant e, assim, apoiadores de uma concepção principiológica e apolítica dos direitos humanos, como Tim Scanlon, têm abraçado tais direitos programáticos. Este explica que a diferença vis-à-vis os direitos negativos, estabelecidos há bastante tempo, se baseia na medida em que o Estado tem o dever de desenvolver "estratégias específicas" 142 para o reforço do direito em questão: "O que são às vezes chamados direitos de bem-estar ou humanitários", escreve, "diferem dos tradicionais direitos civis ou pessoais nesse aspecto". ${ }^{143}$ Especificamente, o governo goza de maior liberdade ao escolher os meios de implementação em relação aos primeiros do que aos últimos. Apesar dessa distinção, Scanlon provavelmente manteria ambos os tipos de direitos dentro da categoria mais ampla de direitos humanos.

Fornece a seguinte explicação:

Por exemplo, quando pessoas falam de "direito a uma alimentação adequada", não estão apenas dizendo que é uma coisa muito ruim ficar sem comida suficiente. Também estão, acredito, expressando um julgamento de que instituições políticas devem ter responsabilidade nessa área. Se elas que não tomam passos adequados para impedir a fome entre seus cidadãos (e, pode-se acrescentar, entre outros), não estão em condições mínimas de legitimidade. É essa conexão entre autoridade e responsabilidade institucional que faz apropriado falar aqui de um direito. ${ }^{144}$

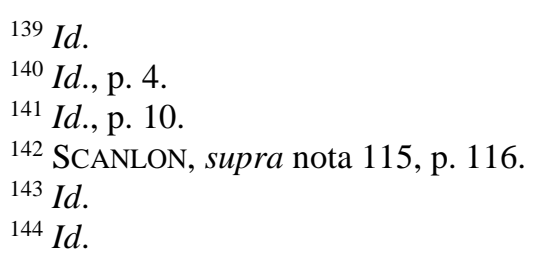


Sob pena de sanção por estar violando a esse direito, o governo deve construir uma bemelaborada política pública com o fim de fornecer nutrição adequada aos seus cidadãos. Obviamente, não tem a obrigação de tomar o melhor curso possível de ação, nem de proteger cada pessoa da desnutrição.

O movimento bolivariano ainda poderia adicionar que mesmo os chamados direitos negativos, que requerem que as autoridades se abstenham de certas ações, necessitam de uma análise equivalente. Por exemplo, o Estado deve adotar medidas sensíveis para reforçar o direito à igualdade com relação às oportunidades de educação primária. Deve prevenir que grupos desfavorecidos recebam uma educação deficiente. Porém não precisa lhes dar acesso a uma aula ou a uma atividade extracurricular em particular, nem garantir que todos os seus membros irão prosperar academicamente, nem demonstrar que optou pelo melhor plano disponível.

As autoridades governamentais merecem ampla liberdade quanto à dimensão política de qualquer direito, seja civil, político, social, econômico ou cultural. Além do mais, têm a maior expertise e legitimidade em matéria de política pública. Consequentemente, um tribunal não deve questionar decisões governamentais nesse sentido. ${ }^{145}$ Além disso, deve aceitar que alguns regimes lidam de modo diferente com relação ao mesmo problema.

Ronald Dworkin e Jürgen Habermas poderiam conceder essas variações. O primeiro reconhece que o mesmo conceito de um determinado princípio pode implicar uma multiplicidade de concepções alternativas. ${ }^{146} \mathrm{O}$ outro, por sua vez, reconhece que os direitos básicos permitem uma variedade de interpretações de uma sociedade à outra. ${ }^{147} \mathrm{~A}$ amplitude interpretativa em cada uma dessas opiniões poderia derivar da influência da política pública ou de fatores ético-políticos.

No entanto, Dworkin se distanciaria dessa posição geral. Entende as várias concepções não como igualmente legitimas, mais como estando em competição entre si em relação à sua correção ou à verdade. Sugere que uma comunidade que constitucionalmente aplica um

\footnotetext{
${ }^{145}$ Ver, e.g., West Coast Hotel Co. v. Parrish, 300 U.S. 379, 399 (1937) ("Mesmo que a sensatez da política seja tomada como discutível e seus efeitos incertos, a legislatura tem direito ao seu julgamento.").

${ }^{146}$ DWORKIN, RIGHTS, supra nota 113, pp. 134-136. Ver também RONALD DWORKIN, LAW's EMPIRE 71 (1986) ("Num primeiro nível o acordo gira em torno de discretas ideias que são sempre empregadas em todas as interpretações; num segundo, a controvérsia latente nessa abstração é identificada e retomada.")

${ }^{147}$ HABERMAS, FG, supra nota 109,, p. 1162 ("Consequentemente, as seções que enumeram direitos fundamentais em várias constituições históricas podem ser entendidas como interpretações contextuais do mesmo sistema de direitos."). Ver também, id., p. 163, 226, 238, 379, 527; HABERMAS, EA, supra nota 110, pp. 245, 263.
} 
conceito específico e delega aos tomadores de decisão a definição de uma concepção correlata "assume que uma concepção é superior à outra." 148 De qualquer forma, Ele certamente insistiria em separar com cuidado princípios de políticas públicas e negar que estas podem servir para elaborar aqueles.

Em contraste, Habermas embarcaria satisfeito no caminho delineado. Explicitamente admite que "o processo de realização legal [de direitos] se desdobra em contextos que também demandam discursos de autoconhecimento como componentes importantes da política: discussões sobre uma concepção comum de bem e sobre a forma de vida cujo reconhecimento autêntico é procurado." ${ }^{149}$ Elucida que:

Certamente, as decisões e políticas dos legisladores devem ser interpretadas, respectivamente, como realizações e elaborações do sistema de direitos. No entanto, quanto mais concreto seja o tópico em consideração mais se expressa também o autoconhecimento da coletividade, junto à correspondente forma de vida, . . . na resultante regulação legal. . . ${ }^{150}$

Consequentemente, quando desenvolvidos numa constituição ou, acima de tudo, numa lei, os direitos humanos internalizam política, ações governamentais, valores e concepções do que é bom. Habermas fala no sentido da "impregnação ética de toda comunidade legal, assim como de todo processo democrático dedicado à realização de direitos fundamentais." 151

Desse ponto de vista, a implementação de um direito em particular frequentemente implica transcender o reino do princípio e transitar na política. A liberdade religiosa exemplifica esta situação. De um lado, as autoridades podem implementar esse direito de uma maneira principiológica se abstendo de suprimir qualquer fé. De outro, podem proceder politicamente e honrar um compromisso legal de apoiar grupos cívicos em geral pela distribuição de concessões a cada credo de forma igual. Quase inevitavelmente, vão passar da primeira para a segunda abordagem e aumentar a sua margem de manobra uma vez que intensifiquem os seus esforços em nome do direito em questão. Isto resultará numa ação que, enquanto totalmente justificável politicamente, se diferirá daquela das suas homólogas menos engajadas. Desse modo, regimes dedicados ao progressismo em diferentes níveis podem coexistir e ter seu lugar dentro do mesmo esquema de direitos humanos.

\footnotetext{
${ }^{148}$ DWORKIN, RIGHTS, supra nota 113, p. 135.

${ }^{149}$ HABERMAS, EA, supra nota 110, p. 254.

${ }^{150} \mathrm{Id}$.

${ }^{151} I d .$, p. 255.
} 
Não obstante a rejeição de direitos positivos, Williams também enfatiza "a importância de se pensar politicamente sobre a violação de direitos humanos." 152 Assim, procura ressaltar "a realidade à custa de abstração filosófica." 153 Além de averiguar filosoficamente se tais infrações, viz., "práticas envolvendo coerção sem legitimação,"154 têm ocorrido, se deve decidir como reagir, o que constitui, de acordo com ele, "sempre uma questão política."155

Ele alerta "que o político não simplesmente exclui, senão inclui o princípio, além de outras coisas." ${ }^{" 156} \mathrm{Na}$ opinião dele, a política se inicia com uma averiguação principiológica e filosófica da possibilidade de uma violação de direitos humanos na forma de "coerção não mediada" ${ } 157$ ter ocorrido. Depois disso, deve-se considerar uma ampla gama de fatores antes de determinar o que fazer, se algo, sobre a atual violação.

No final de tudo, ele defere completamente aos governos. Conclui que estes devem honrar somente um número reduzido de direitos negativos, evidentes e universais, relacionados à "coerção injusta."158 Além disso, os Estados opressores não deveriam ser condenados caso pudessem "demonstrar que a coerção é legítima." 159 Alerta, contudo, que a justificativa deve se basear num "sistema de crenças" que não pode "ser razoavelmente interpretado como (para utilizar termos improvavelmente simples) de sustentação da dominação."160

Em outras palavras, outorga à política um extremamente amplo campo de operações irrestritas. Ele efetivamente confere carta branca às autoridades desde que não coajam seus cidadãos. Notadamente, toleraria mesmo um regime coercivo se a liderança pudesse formular uma reivindicação razoável de legitimidade.

Coincidentemente, Habermas e Williams consideram que a ação política não apenas toca mas também permanece externa aos direitos humanos. Para ser mais exato, provavelmente reconheceriam a dificuldade de se desenhar uma linha clara que separe o interior principiológico de tais direitos do seu exterior político. Na verdade, contudo, se o elemento

\footnotetext{
152 Williams, supra nota 119 , p. 3.

${ }^{153} I d$.

154 Id., p. 11.

155 Id., p. 13.

${ }^{156} \mathrm{Id}$.

157 Williams, supra nota 119, p. 12.

${ }^{158} I d$.

${ }^{159}$ Id., p. 11.

${ }^{160}$ Id., p. 12.
} 
político impacta os direitos humanos de forma endógena ou exógena não interessa muito. Por exemplo, o governo se conduz de igual forma ao subsidiar todas as organizações religiosas através do exercício da sua discrição política, que em apoio à liberdade religiosa. Apenas parece se beneficiar de uma defesa mais sólida no último do que no cenário anterior contra indivíduos reclamando de um ataque governamental sobre os seus direitos. Em qualquer caso, as autoridades devem afirmar de forma categórica que a alegada violação aconteceu no processo de defesa das liberdades religiosas.

De todos modos, o Eixo Bolivariano pretende, sob a interpretação elaborada na Seção I(C), ir além da asserção de que os direitos humanos possuem uma dimensão política. Estão, de fato, propondo que tais direitos sejam apenas políticos e nada mais. Ou seja, o componente principiológico desaparece completamente.

Tal posição traz à mente o que foi argumentado pelo realismo jurídico estadunidense e, mais tarde, pelo movimento de estudos jurídicos críticos (Critical Legal Studies Movement). Essas escolas procuram, em parte, abandonar noções como "formalismo e objetivismo" com o objetivo de postular um entendimento do direito como sendo um meio de alcançar objetivos políticos reformistas ou "de esquerda". ${ }^{161}$ As nações dissidentes dentro do Sistema Interamericano de Direitos Humanos parecem estar fazendo uma campanha equivalente com respeito a direitos humanos ao invés do direito como um todo.

Apesar dessa convergência, a parcela dissidente dentro da Organização dos Estados Americanos tem assumido uma posição que diverge dos mencionados modelos instrumentalistas. Certamente não tem afirmado que as cortes deveriam impor sua própria agenda política contra aquela dos poderes Executivo e Legislativo do governo. Pelo contrário, insiste, como previamente exposto, que os juízes devem normalmente abraçar e apoiar as políticas públicas das autoridades eleitas.

Essa postura não se resume à ideia aparentemente conservadora de que os juízes devem sempre se submeter às autoridades políticas, sejam boas ou ruins. Pelo contrário, incorpora um pedido caloroso por políticas progressistas. Desse prisma, se o governo se dedica à

\footnotetext{
${ }^{161}$ Ver, e.g., Roberto Mangabeira Unger, The Critical Legal StUdies Movement 3-4 (1983) (“Se a crítica do formalismo e do objetivismo é o primeiro tema característico de movimentos de esquerda no pensamento legal moderno, a utilização puramente instrumental tanto da prática quanto da doutrina legal para o avanço os propósitos de esquerda é o segundo.”).
} 
emancipação, os tribunais devem se mostrar favoráveis. Se é opressivo, contudo, falta-lhes capacidade de fazer a diferença e se tornam inúteis. Sob tais circunstâncias, os cidadãos não deveriam levar suas reclamações aos tribunais, mas, ao invés disso, às ruas para tentar subverter a ordem existente.

A Venezuela e seus aliados afirmariam, especificamente, que qualquer direito humano deveria servir para alcançar justiça social. Demandariam a submissão do Judiciário porque, como Estados, participaram da promulgação da Convenção Americana; porque, como governos, se especializam e legitimam em política; e acima de tudo, porque têm colocado em prática um formidável projeto de revolução política. Dessa ótica, a Comissão Interamericana e a Corte de Direitos Humanos estão impedindo essa nobre cruzada pela emancipação política e deveriam, portanto, ao menos não obstruir o caminho. O bloco de esquerda da região, por sua parte, deveria vigorosamente se concentrar na política e no direito com o intuito de manter esses organismos em xeque e, por último, forçá-los ou a mudar ou a desaparecer.

\section{SÍNTESE}

Mesmo assim, talvez não se deveriam abandonar os princípios tão rapidamente. De fato, pode-se fazer um esforço para preservá-los, ao menos para transmitir a ideia de que um direito humano geralmente contém um elemento normativo e que o Estado merece apenas liberdade limitada nessa área. O Judiciário e a sociedade como um todo deveriam ampliar sua submissão às autoridades somente em relação a outras matérias, e.g., aquelas que pertencem ao domínio político.

Assim, um direito essencialmente incorpora um princípio ou uma norma. De forma paradigmática, postula uma obrigação e requer uma efetivação, principalmente, determinando se indivíduos ou entidades têm cumprido ou não. Quando autoridades públicas desprezam o princípio implícito num direito, devem indubitavelmente sofrer reprovação e sanção.

Se os direitos não forem mais que políticas públicas e se basearem em meros valores ou objetivos, os tribunais internacionais ou constitucionais dificilmente teriam um papel construtivo a exercer. No início, o governo simplesmente consideraria várias políticas públicas e agiria como julgasse apropriado. Depois disso, os juízes não poderiam sensatamente concluir 
que a ação "violou" alguma política pública, nem mesmo uma desfavorecida ou descartada. Poderiam, no máximo, culpar o regime por desconsiderar algumas das políticas públicas enumeradas e exigir que delibere novamente. Se o Judiciário, ao invés disso, escolher reiterar ele mesmo a avaliação original, estaria se engajando num exercício aparentemente inútil e injustificado.

Como mencionado na seção anterior, os direitos possuem uma dimensão política. Assim como as normas que encarnam, podem requisitar concretização por meio de política pública. E nessa situação o governo caracteristicamente atua com considerável margem para erro.

O direito à privacidade pode ajudar a ilustrar o ponto. Da presente perspectiva expressa não uma política pública particular mas o princípio de que o Estado não deveria invadir a intimidade das pessoas. Quando as autoridades espionam cidadãos somente para manter um olho sobre uma potencial dissidência, atropelam essa norma e devem encarar um controle estrito. Contudo, quando lançam um programa para, por exemplo, o desenvolvimento e a distribuição de um software que a população pode manejar como um escudo contra a espionagem pública e privada, podem com certeza exigir um amplo (mas não infinito) espaço de atuação. Sem dúvida, diferenciar o primeiro tipo de cenário do último irá constantemente criar complicações e polêmicas.

Claro, um esquema conceitual diferente poderia servir igualmente para articular essa alternância, na realização dos direitos humanos, entre altos e baixos níveis de liberdade gozados pelo governo. Por exemplo, Bernard Williams se apoia na expressão "coerção não mediada", ${ }^{162}$ como um princípio superior, para descrever as raras situações nas quais ele toleraria uma interferência externa nos negócios governamentais. Propõe conceder às autoridades carta branca em todos os outros casos.

Por fim, desenha estreitamente o círculo das situações nas quais uma intervenção pode ocorrer legitimamente. Deixa ao governo extensa liberdade não somente com respeito a direitos políticos e civis cuja violação não constitui uma opressão crassa, mas também a todos os direitos

${ }^{162}$ Williams, supra nota 119, p. 14. 
econômicos, sociais e culturais. Acredita que não se pode, de forma persuasiva qualquer, defender a imposição de todos esses direitos desde fora da sociedade. ${ }^{163}$

Curiosamente, nunca contempla se um tribunal transnacional poderia legitimamente intervir pela mera referência a tratados ratificados pelos regimes que estão enfrentando acusações de abusos de direitos humanos. E não o faz, presumivelmente, porque foca nas situações nas quais os alegados opressores comandam comunidades que não reconhecem as normas que os estranhos pretendem impor. ${ }^{164}$ Mais precisamente, está tentando descobrir a medida na qual a moralidade per se, independente do direito internacional, permite uma condenação em tal cenário.

O conceito de um princípio ou de um direito não tem que exibir todas as características comumente associadas a ele. Por exemplo, pode-se negar a universalidade e o caráter absoluto aparentemente atribuído por Ronald Dworkin e outros. O trabalho de Richard Rorty, referenciado na Seção II(A), serve como um lembrete dos problemas que tais atribuições criam.

Os direitos humanos principiológicos codificados não precisam refletir qualquer catálogo transcendental de direitos humanos morais. No entanto, encontraram um lar na maioria das culturas, assim como no direito internacional, e obrigam quase categoricamente porque se baseiam em noções amplamente compartilhadas e cruciais, como as de razoabilidade, justificação e aceitabilidade. Podem-se defender com uma ampla gama de argumentos atraentes e contundentes.

Por exemplo, tal argumentação, em conjunto com uma batalha campal para o empoderamento das mulheres, tem levado a muitas nações a reconhecerem um direito quase incondicional contra a discriminação sexual. Incontestavelmente, uma cultura atual ainda poderia rejeitar esse direito de forma aberta e esmagadora, exigindo uma exceção ao amplo princípio da equidade. Destarte se exporia a críticas, seja por insensibilidade, crueldade,

\footnotetext{
${ }^{163}$ Ver id., p. 12 "É uma marca do bom senso filosófico," de acordo com Williams, "que a acusação" de que a prática [de determinado ato] viola direitos humanos fundamentais "não deve ser interpretada de qualquer forma; além do mais, as nossas teorias não devem nos levar a tratar como crimes manifestos toda prática que rejeitamos no princípio liberal e que não poderia ser aceita aqui - especialmente se na sua localidade ela puder ser tomada como legítima." Id.

${ }^{164}$ Ver id., p. 10 ("Complicações conceituais multiplicam quando se está envolvido num caso diferente cujo argumento de legitimação que foi aceito numa época ainda é aceito em alguns lugares, mas recusado em outros.") Na visão de Williams, “o mundo contemporâneo está certamente ao alcance do passado, e as influências do passado incluem, agora, concepções teocráticas de governo e ideias patriarcais dos direitos das mulheres.” Id.
} 
ignorância ou até mesmo sexismo, mas não necessariamente por falhar em entender a universalidade ou o caráter absoluto do direito. Em relação a uma tão improvável coletividade nacional, talvez devêssemos nos abster de depreciá-la como irracional e de esperar trazê-la, com uma repreensão moral, aos caminhos adequados.

Tim Scanlon, por sua vez, se posiciona pela renúncia de um universalismo rígido: “Os julgamentos empíricos nos quais os direitos são baseados pressupõem certas condições de fundo. . . . Essas condições não são universais, embora no caso de vários direitos comumente listados como 'direitos humanos' são suficientemente difundidas para serem consideradas gerais em todos propósitos práticos. " ${ }^{165}$ Especificamente, afirma que o objetivo que sustenta tais direitos, ou seja, "o de promover uma aceitável distribuição de controle sobre porções importantes das nossas vidas ... seria importante às pessoas num grande número de sociedades, mas naturalmente não em todas."166 Finalmente, declara, ecoando Jürgen Habermas, que "os direitos particulares que [esse objetivo] demanda podem variar entre sociedades."167

Por fim, poder-se-ia até defender o "relativismo de distância" de Williams, segundo o qual "ninguém é compelido a estender todas as suas opiniões morais, particularmente sobre direitos, ao passado."168 Tais direitos se aplicam unicamente às sociedades contemporâneas. "No que diz respeito a direitos humanos," Williams elucida, "o que importa é o que se passa hoje no nosso mundo, agora. Nesse sentido, o passado não é outro país: se fosse apenas outro país nós deveríamos talvez nos perguntar o que fazer." 169

Com relação aos Estados modernos, as cortes globais poderiam, ao efetivar a panaceia de direitos humanos, não apenas ceder às autoridades nas questões de políticas, mas também consistentemente mostrar considerável sensitividade cultural. Por exemplo, poderiam se mostrar flexíveis caso uma nação como a Argentina, estando ciente da sua história, restringir os direitos de associação de grupos cívicos que advogam o retorno dos militares ao poder ou da condenável campanha de suprimir suspeitos de subversão. Tal atitude judicial geral deveria, ceteris paribus, reduzir o risco de intrusão exógena ilegítima.

\footnotetext{
165 SCANLON, supra nota 115 , p. 116.

166 ThOMAs M. SCANLON, Rights, Goals, and Fairness, in THE DifFICUlty of TOLERANCE: EsSAYS IN POLITICAL PHILOSOPHY 26, 36 (2003).

${ }^{167}$ Id.

168 Williams, supra nota 119, p. 8.

${ }^{169}$ Id., p. 9.
} 
Na elucidação do seu ponto de vista, Scanlon afirma ainda que os direitos humanos não precisam ser absolutamente vinculantes. Embora lhes atribua um enorme peso, prudentemente evita lhes conferir caráter absoluto: "Enquanto eu nunca tomaria a posição extrema de que os direitos humanos jamais devem ser violados - não importando as consequências -,diria que as situações nas quais as violações poderiam ser justificadas teriam que ser bastante extremas."170

Williams leva essa concessão global um passo adiante. Como se discutiu na seção anterior, descreve a pergunta de como responder a demonstráveis violações de direitos humanos como política e aberta. De fato, aconselharia contra uma interferência, "sendo os outros fatores iguais (o que é uma enorme restrição)," exceto "se a violação for desmedida." ${ }^{171}$ Ele aduz as seguintes bases para encorajar o envolvimento internacional contra, e somente contra, transgressões exorbitantes:

Bom, (1) o que está acontecendo já é péssimo. (2) Em outros casos é mais provável que a intervenção pioraria as coisas. (3) [Num] caso que se assemelhe menos a um de coerção não mediada, as vítimas poderiam não pensar que são vítimas e então uma intervenção poderia resultar difícil de se distinguir do imperialismo ideológico. Mas, basicamente, (4) quanto mais próximo do paradigma estiverem as violações e quanto mais o Estado for parte do problema, mais a situação pode ser a do aparato estatal em guerra contra o seu próprio povo. ${ }^{172}$

Mesmo assim, recomendaria, como regra, intervir contra limitações da liberdade de expressão; porque ela "é essencial para a efetividade de qualquer crítica às ações estatais, em relação à uma concepção razoável do interesse individual." ${ }^{173}$

Se um Estado assina as principais convenções de direitos humanos, mesmo Williams e outros céticos deveriam endossar a responsabilização dele. Em outras palavras, deveriam aceitar poucas exceções à obrigatoriedade dos direitos acordados. De qualquer forma, um sistema de direitos humanos que ocasionalmente isentasse as autoridades não se tornaria por isso uma aberração nem seria disfuncional.

Naturalmente, deve-se ter um senso preciso de quando uma exceção será aceita, porque o governo vai tender a recorrer a ela com frequência. Um tratado de direitos humanos ou o

\footnotetext{
${ }^{170}$ SCANLON, supra nota 115, p. 121. "Mas dizer que uma regra ou direito não está, em geral, sujeita a exceções justificadas em bases ao utilitarismo de ato," de acordo com Scanlon, "não é dizer que ela é absoluta. Pode-se questionar a importância de se preservar uma igual distribuição de controle do tipo em questão, e indubitavelmente haverá algumas coisas que superarão este valor." SCANLON, supra nota 165, p. 34.

${ }^{171}$ Williams, supra nota 119, p. 13.

${ }^{172} I d$.

${ }^{173}$ Id., p. 14.
} 
Judiciário deveriam resolver a questão. Caso contrário, as autoridades irão certamente decidir elas mesmas e provavelmente negligenciar os direitos quando o julgarem adequado.

Por exemplo, um regime pode confrontar uma tentativa de golpe e banir programas televisivos oposicionistas temporariamente. Também pode suspender seus programas de proteção ambiental e desviar a equipe responsável por eles a outras tarefas mais urgentes. Um tribunal supranacional poderia reconhecer uma violação de direitos básicos, mas se abster de sancionar o Estado durante a subversão em andamento.

Os juízes teriam que monitorar toda a questão de perto. Teriam que desconfiar das afirmações oficiais pertinentes à emergência e da adequação da reação posterior. Um governo tem todos os incentivos para exagerar ou criar uma crise com objetivo de colocar os direitos de cidadania de lado.

Já que a justiça social pode entrar em conflito com os direitos fundamentais, pode analogamente autorizar ou mesmo exigir a sua suspensão provisória deles. O então Presidente da Venezuela, Hugo Chávez, claramente pensou que havia chegado a tal situação quando "ordenou aos hotéis com vagas a abrigar milhares de pessoas que perderam suas casas por conta de uma inundação" em dezembro de 2010. ${ }^{174}$ Poderia ter afirmado apropriadamente que tratar os desabrigados corretamente demandava colocar de lado os direitos de propriedade dos hoteleiros. Mesmo assim, deve-se resistir à tentação de sustentar que a sua administração estava adequadamente restringindo esses direitos em favor do direito à moradia. Em outras palavras, este não obriga nem as autoridades nem ninguém a garantir que qualquer pessoa tenha hospedagem.

Em suma, os direitos humanos geralmente giram em torno de razões e geram obrigações, mas não precisam ter compatibilidade com uma série de direitos morais transcendentes. Além disso, não têm que operar universal ou absolutamente, mesmo quando fundados em princípios. Como consequência, um regime pode ignorar certos direitos em razão de serem inaplicáveis seja pelo contexto cultural ou devido a um transe urgente e de curto prazo. No entanto, pode

\footnotetext{
${ }^{174}$ Simon Romero, 21 Bodies Found in Colombia Mudslide; Dozens Feared Dead, N.Y. TimES (7 de dez. de 2010), p. A11.
} 
agir assim só em situações excepcionais, suportando um considerável ônus de persuasão argumentativa.

Como notado, os direitos humanos se correlacionam intricadamente com a justiça social. Tendem a fomentá-la, mas não a garante, e podem, em circunstâncias extremas, limitá-la. E mais, o Eixo Bolivariano pode se comprometer com tais direitos como parte da sua luta por uma sociedade justa. Mas também pode ir além ou até mesmo contra direitos humanos em nome de uma justa causa maior. No entanto, os cidadãos devem ordinariamente poder reivindicar contra seu governo quaisquer direitos normativos e insistir em que estes sejam respeitados.

De qualquer modo, os princípios não exaurem a definição de direitos, nem mesmo dos direitos negativos. Similarmente, direitos positivos não têm a ver exclusivamente com a política pública. Pode-se afirmar que os direitos possuem tanto uma dimensão normativa quanto uma política e que as autoridades devem desfrutar de menos discrição quanto à primeira e mais quanto à última. Nesse sentido, os juízes devem ou escrutinizar estritamente ou olhar com deferência para o engajamento governamental, dependendo se se apoiar predominantemente sobre os princípios ou sobre a política dos direitos humanos.

Como concebidos na Seção III(B), os direitos políticos e civis parecem descansar muito sobre princípios e, por isso, clamam por uma mais exata revisão judicial. Os direitos econômicos, sociais e culturais, por sua vez, parecem gravitar na zona da política pública e, assim, permitem que o Estado tenha mais espaço de manobra. A oposição entre uma clássica disputa sobre a liberdade de associação e uma sobre o direito à moradia serve para iluminar essa dicotomia. De um lado, o Judiciário pode responsabilizar severamente as autoridades quando proíbem, como repreensão à dissidência, a reunião de um determinado grupo. E de outro, elas merecem o benefício da dúvida quando se analisar as medidas para aumentar a oferta de residências em razão do direito à moradia.

Em geral, cada um desses direitos se baseia em uma das normas definidas a seguir: (1) “Os cidadãos terão direito a se associarem livremente entre si”" e (2) "As pessoas terão direito à moradia." Uma violação direta ocorre mais comumente contra o primeiro princípio do que contra o segundo. De fato, os governos vão mais frequentemente banir certas organizações, como o partido comunista, do que demolir moradias privadas. Claro, em qualquer cenário, o agredido deve poder procurar a intercessão de um tribunal. 
De outro modo, a política pública parece ter um papel mais proeminente com respeito a direitos positivos do que com respeito a direitos negativos. Os primeiros parecem necessitar, mais claramente do que os segundos, da utilização da burocracia do estado de bem-estar e da adoção de um plano gradual e planejado de longo prazo. Consequentemente, o governo normalmente concretiza o direito à moradia por meio da construção de complexos de apartamentos públicos, utilizando a concessão de subsídios e a redução de tributos aos compradores etc.

Em contraste, as autoridades honram a liberdade de associação, acima de tudo, simplesmente dando direito a grupos para se mobilizarem e se reunirem. Apenas secundariamente procedem por meio de políticas públicas mais elaboradas, como a concessão de subvenções associativas, de status de organização sem fins lucrativos para aquelas que se qualificam e assim em diante. De fato, um regime poderia, embora não devesse, escapar totalmente da sua responsabilidade limitando-se ao primeiro passo e recusando-se inteiramente a dar o segundo - ou seja, adotando uma abordagem baseada unicamente na não-ingerência.

Independentemente do direito em questão, os requerentes geralmente não terão sucesso numa reclamação contra uma política pública oficial a não ser que demonstrem que o governo tem agido arbitrariamente ou deixado de fazer algo. Significativamente, tal demonstração sugeriria que as autoridades têm violado, ao menos indiretamente, a norma implícita. Portanto, a fiscalização jurídica de medidas governamentais, em última instância, equivale a aplicar o princípio correspondente.

Pode-se reformular simplesmente e distorcer um pouco essa postura da seguinte forma. (1) O Estado deve realizar uma série de ações sob pena de reprovação social ou judicial por violar a norma. (2) Deve optar por uma ou várias estratégias burocráticas prolongadas e comete uma infração tanto se o fizer de forma arbitrária ou se se abstiver por completo.

As autoridades manifestamente gozam de uma menor discrição quanto ao primeiro do que ao segundo tipo de responsabilidade. Além disso, podem mais facilmente violar o princípio subjacente quanto ao primeiro do que ao segundo, sobre o qual correm mais risco de erro de cálculo político. Finalmente, o governo geralmente enfrenta um controle maior quanto aos direitos políticos e civis, como o direito à associação, do que aos direitos sociais, econômicos e culturais, como o direito à moradia. 
Estranhamente, quase todas as controvérsias que têm causado comoção no Sistema Interamericano de Direitos Humanos têm versado sobre direitos negativos. Venezuela, Equador, Bolívia e Nicarágua têm repetidamente reclamado de decisões sobre liberdade de expressão assim como da Relatoria da Comissão Interamericana de Direitos Humanos para a Liberdade de Expressão. Além disso, a Denúncia e a Fundamentação venezuelanas miram seis decisões envolvendo direitos políticos e civis: duas a liberdade de expressão, duas o devido processo legal, uma sobre perseguição política e outra sobre tratamento desumano.

Nessas disputas presumivelmente principiológicas, a Comissão e a Corte deviam às autoridades pouca margem de manobra. No entanto, a Venezuela parece ter esperado uma ampla liberdade de ação. Observou, aparentemente tentando apresentar o seu posicionamento como legítimo, que todas as petições vieram de indivíduos moral e politicamente questionáveis: a saber, (1) de jornalistas "de grande beligerância contra o governo," "175 (2) de um advogado acusado de "crime de conspiração," ${ }^{176}$ (3) de um político de oposição acusado de agir "em favor do golpe de 11 de abril de 2002,"177 (4) de um general "insurrecionado""178, (5) de um "terrorista . . condenado" "179 por ataques a bomba "destinados a desestabilizar a democracia na Venezuela," 180 e (6) de três juízes que "incorreram em "grave erro judicial de caráter inexcusável." ${ }^{181}$ Contudo, o suposto desvalor dos requerentes deveria levar os tomadores de decisão transnacionais para uma maior, ao invés de menor, vigilância. As autoridades tipicamente respeitam os direitos de indivíduos impopulares muito menos do que o de outros.

$\mathrm{Na}$ outra ponta do espectro, os tribunais não deveriam oferecer carta branca aos governos no que concernir aos direitos positivos altamente políticos. Como pontuado, devem conceder-lhe liberdade substancial, mas não devem abdicar dos seus deveres. Tais direitos se qualificam como direitos precisamente porque impõem às autoridades obrigações passíveis de controle judicial. Caso contrário, se reduziriam a meras recomendações.

Como submetido na Seção II(B), os juízes devem interpretar tais direitos como programáticos. Por conseguinte, devem ordenar ao Estado que mostre o desenvolvimento de

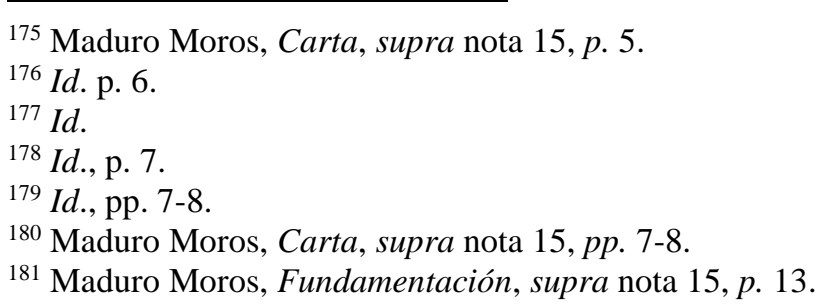


um programa sério a respeito do direito em questão. As autoridades eleitas, por outro lado, merecem deferência quanto aos detalhes, embora não à necessidade de se engajar. Devem sofrer admoestação caso negligenciarem tomar alguma decisão ou agirem de forma descompassada.

Naturalmente, estabelecer se um determinado desafio gira em torno de princípio ou política (politics) criará recorrentemente discussões e discordâncias implacáveis. Isso irá invariavelmente colocar o Estado contra seus cidadãos e o Judiciário. No entanto, o debate sobre direitos humanos irá, de todo modo, se revelar mais inteligível se focar nesse esquema de dupla conceituação.

\section{ADJUDICAÇÃO}

Refletir sobre direitos positivos e negativos no contexto da litigância da vida real irá com certeza contribuir para um melhor entendimento não apenas do jogo entre seus componentes principiológicos e políticos, mas também de até que ponto os juízes poderão ceder ao governo. Assim, a discussão irá atravessar oito casos e irá interpretar quatro deles como decididos em princípios, que demandam rigorosa aderência, e quatro deles voltados à política pública, a respeito da qual o governo possui uma razoável quantidade de liberdade. Cada um desses dois grupos irá incluir duas decisões (uma nacional, uma internacional) envolvendo liberdade de expressão e mais duas paralelas que se referem ao direito à saúde.

Como questão de princípio, as autoridades geralmente não podem reprimir discurso com base na sua repulsa pelas maneiras ou mensagens de quem fala. Em Cohen v. California, ${ }^{182}$ por exemplo, o Estado condenou o apelante por ter se apresentado à corte "vestindo uma jaqueta com as palavras 'Fuck the Draft' que estavam plenamente visíveis." 183 O Tribunal Supremo dos Estados Unidos persuasivamente encontrou uma violação da "regra usual de que os órgãos governamentais não devem prescrever a forma ou o conteúdo da expressão individual."184 Posicionou-se da seguinte forma:

O direito constitucional de liberdade de expressão é um forte remédio numa sociedade diversa e populosa como a nossa. É designado para a remoção das amarras

\footnotetext{
182403 U.S. 15 (1971).

${ }^{183}$ Id., p. 16.

${ }^{184}$ Id., p. 24.
} 
governamentais da arena de discussão pública, colocando a decisão sobre quais visões devem ser ouvidas amplamente nas mãos de cada um de nós, na esperança de que a utilização de tal liberdade irá em último caso produzir uma cidadania mais capaz e uma política mais perfeita, na crença de que nenhuma outra abordagem irá comportar a premissa de dignidade e escolha individual sobre a qual o nosso sistema politico está baseado. ${ }^{185}$

Os juízes não ofereceram às autoridades da Califórnia muito espaço para descrever as palavras censuradas como uma perturbação da paz ou como inerentemente ofensivas. ${ }^{186}$

De forma semelhante, em Olmedo v. Chile ${ }^{187}$ o Estado chileno baniu o filme A Última Tentação de Cristo. Mais precisamente, a Corte de Apelação de Santiago decidiu, e o Tribunal Supremo chileno confirmou, um mandado de segurança em nome da Igreja Católica contra o

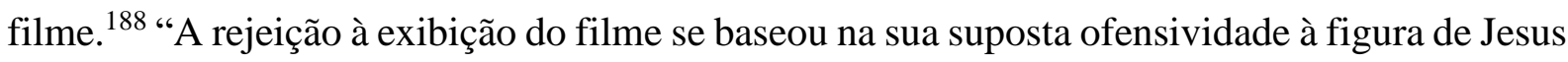
Cristo." 189 A Corte Interamericana de Direitos Humanos pronunciou a restrição "como uma censura prévia em violação da [liberdade de pensamento e expressão preservada] no Artigo 13 da Convenção [Americana]. ${ }^{190}$ Depois disso, deduziu que "o Estado descumpriu as obrigações gerais de respeitar e garantir os direitos protegidos pela Convenção e de adaptar o ordenamento jurídico interno às suas disposições dela. ${ }^{191}$

Depois de verificar uma violação inequívoca sob a limitação normativa em prévias restrições à liberdade de expressão, a maioria gastou pouco tempo nas tentativas dos tribunais nacionais de caracterizar o filme como abominável ou nas tentativas do Poder Executivo de reformar a Constituição para banir toda censura. Os magistrados expressaram estima e ressaltaram a importância da "iniciativa do governo de propor a mencionada reforma constitucional.” ${ }^{~} 192$ No entanto, observando que o descumprimento persistia, ${ }^{193}$ resolveram que “o Estado [devia] modificar seu sistema jurídico interno em um tempo razoável a fim de

\footnotetext{
${ }^{185} I d$.

${ }^{186}$ Ver id., pp. 22-23 (negando à "Califórnia" a autoridade de "extirpar . . . um particular epíteto grosseiro do discurso público, tanto sobre a teoria da corte descrita abaixo de que o seu uso é inerentemente provável de causar reação violenta quanto se baseando numa asserção mais geral dos Estados atuando como guardiões da moralidade pública.")

${ }^{187}$ Olmedo Bustos ("La Última Tentación de Cristo") vs. Chile, Ct. Inter-Am. D.H. (Ser. C) No. 73 (5 de fev. de 2001).

${ }^{188}$ Id., p. 22 (II 60(e)).

${ }^{189} I d .$, p. 24 (II 61(h)).

${ }^{190} I d$., p. 29 (II 71$)$.

${ }^{191} I d$., p. 36 (II 90).

192 Olmedo Bustos ("La Última Tentación de Cristo") vs. Chile, Ct. Inter-Am. D.H. (Ser. C) No. 73 (5 de fev. de 2001), p. 35 (II 89).

${ }^{193}$ Olmedo Bustos ("La Última Tentación de Cristo") vs. Chile, Ct. Inter-Am. D.H. (Ser. C) No. 73 (5 de fev. de 2001), p. 35 (II 89).
} 
suprimir a censura prévia para permitir a exibição do filme . . . e [devia] entregar à Corte . . . , dentro de um período de seis meses. . ., um relatório sobre as medidas tomadas a esse respeito."194

Normativamente, o direito à saúde proíbe um regime de negar tratamento médico a uma pessoa. Em Instituto Rural Psiquiátrico v. Ministério da Sanidade e Assistência Social, ${ }^{195}$ por exemplo, várias clínicas processaram o governo venezuelano em razão dele se recusar a renovar contratos delas e assim atropelar o direito à vida e à saúde dos seus pacientes indigentes. ${ }^{196} \mathrm{~A}$ Câmara Política e Administrativa do Tribunal Supremo da Venezuela concordou com os postulantes.

A decisão não deveria surpreender. Além do mais, a administração não se importou com esses doentes mentais crônicos e indivíduos carentes e nem com as suas mais simples necessidades sanitárias; mas contribuiu para a deterioração ao invés do melhoramento das suas condições.

Os juízes venezuelanos também expressaram grande "desaprovação da conduta deplorável do Ministro"197 relatando suas responsabilidades contratuais. A equipe ministerial admitiu "nunca ter intencionado rescindir os contratos."198 Além disso, assegurou, durante a litigância, "os fundos necessários" para a renovação, mas recusou a agir antes do julgamento de mérito. ${ }^{199}$

Como consequência, a mais alta corte da Venezuela julgou as ações oficiais como uma afronta ao direito em questão e à conseguinte obrigação:

Na opinião deste Corte Suprema de Justiça, tal conduta não apenas ameaça abertamente os direitos à vida e à saúde dos doentes mentais em questão, uma vez que o Estado não pode garantir aqueles de forma eficiente sem os recursos necessários. Além do mais, ela torna-se um descumprimento inescusável da obrigação estatal de velar estes cidadãos venezuelanos infortunados e abandonadas que nada podem fazer para melhorar sua situação. ${ }^{200}$

\footnotetext{
${ }^{194}$ Id., p. 39 (II 4). nota 2, pp. 354-361.

${ }^{196}$ Id., p. $355(\S \mathbf{I})$.

${ }^{197} I d$., p. $358(\S \operatorname{IV}(4.2))$.

${ }^{198} I d$.

${ }^{199} I d$.
}

195 Rec. No. 14695 (Pol. \& Adm. Ch.) (Sup. Ct.) (Venez.) (1998), traduzido \& reimpresso em OQUENDO, supra

${ }^{200}$ Rural Psych. Inst. Virgen del Rosario v. Min. Health \& Soc. Wel., Rec. No. 14695 (Pol. \& Adm. Ch.) (Sup. Ct.) (Venez.) (1998), traduzido \& reimpresso em OQUENDO, supra nota 2, pp. 358-359 (§ IV(4.2)). 
Os magistrados ordenaram, portanto, ao governo que contratasse novamente os requerentes e que pagasse pelos serviços prestados após a expiração dos contratos originais. ${ }^{201}$

Mais uma vez, primeiro o tribunal constatou a contravenção de uma norma implícita. Depois, desprezou a "única" justificativa aduzida pelas autoridades: "indisponibilidade de fundos." 202 Os juízes proclamaram que "a única opção moral e legal do Ministério, assim que os recursos se tornaram disponíveis, era prosseguir sem demora ou desculpa à extensão dos contratos existentes ou a uma nova contratação."203

Do mesmo modo, em Vera Vera vs. Equador, ${ }^{204}$ o governo prendeu o requerente por roubo à mão armada e negou-lhe atenção médica pelo dano de uma bala que o atingiu antes da prisão e da qual ele finalmente morreu. A Corte Interamericana de Direitos Humanos verificou "que . . . o Estado não dispensou atenção médica adequada e oportuna ao Sr. Pedro Miguel Vera Vera." ${ }^{205}$ Concluiu, ainda, que "a série de omissões por parte [das autoridades] ao longo do tempo em que [aquele] esteve sob custódia de [estas] constituiu negligência médica que resultou na sua morte e deve implicar responsabilidade internacional."206

Os magistrados constataram unanimemente uma clara violação dos "direitos à integridade pessoal e à vida, ${ }^{207}$ os quais incorporam o direito à saúde. Em relação ao este, a demanda de Comissão Interamericana citou especificamente o Princípio X dos Princípios e Boas Práticas sobre a Proteção das Pessoas Privadas de Liberdade nas Américas: “As pessoas privadas de liberdade terão o direito à saúde, entendida como o desfrute do mais alto nível possível de bem-estar físico, mental e social. . .."208 A decisão final do tribunal explica a interrelação entre todos os três direitos nos seguintes termos:

Os direitos à vida e à integridade pessoal estão direta e imediatamente ligados com a atenção à saúde humana. Nesse sentido, o artigo 10 do Protocolo Adicional à Convenção Americana sobre Direitos Humanos em matéria de Direitos Econômicos e Sociais e Culturais estabelece que toda pessoa tem direito à saúde, entendida como o mais alto nível possível de bem-estar físico, mental e social e indica que a saúde é

${ }^{201} I d$., p. $359(\S \operatorname{IV}(4.2)) ;$ id., p. $360(\S \mathrm{V}(1-2))$.

${ }^{202} I d$., p. $359(\S \mathrm{IV}(4.2)) ; i d .$, p. $360(\S \mathrm{V}(1-2))$.

${ }^{203} \mathrm{Id}$.

${ }^{204}$ Ct. Inter-Am. D.H. (Ser. C) No. 224 (19 de maio de 2011).

${ }^{205}$ Id., p. 32 (II 75).

${ }^{206} \mathrm{Id}$.

${ }^{207}$ Id., p. 33 (II 79). See also id., p. 56 (II 2) (Resoluções).

${ }^{208}$ Demanda ante la Corte Interamericana de Derechos Humanos en el caso de Pedro Miguel Vera Vera y Otros Contra la República de Ecuador, Caso 11.535, Comisión Inter-Am. D.H., OEA/Ser. L/V/II, doc. 5 rev. (24 de fev. de 2010), p. 13 (II 39). 
um bem público. [O] Estado tem o dever, como garante da saúde das pessoas sob sua custódia, de fornecer aos detidos revisão médica regular, assim como atenção e tratamento médicos apropriados sempre que necessário. ${ }^{209}$

A Corte comentou que "a falta de atenção médica adequada descumpre os requisitos materiais mínimos para um tratamento digno de acordo com a condição de ser humano. . .."210

O governo sem dúvida se esquivou dos seus compromissos relacionados ao direito à saúde. Ignorou as circunstâncias médicas urgentes da vítima e materialmente contribuiu para a morte dele. Portanto, os juízes foram apropriadamente rigorosos com as autoridades.

Em todas essas quatro circunstâncias de decisão principiológica, o regime poderia, teoricamente, ter alegado que estavam agindo politicamente. Poderia ter ido além da pura alegação e argumentado que estava na persecução de uma política pública, nas duas primeiras controvérsias, para proteger a moral da comunidade e, nas outras disputas, para salvar recursos sanitários para as doenças fisiológicas dos cidadãos que respeitam a lei. Naturalmente, as autoridades teriam que provar não apenas que a estratégia política levantada realmente existiu como também, muito improvavelmente, que ela não teve, em si mesma, conflito com o princípio pertinente. De fato, teriam que demonstrar que não estavam problematicamente assumindo a prerrogativa de determinar, com base nas suas particulares preferências ou preconceitos, quem deveria falar ou quem deveria receber cuidados médicos.

Nos casos analisados nesta seção até aqui, a sociedade civil e o Judiciário não mostraram muita flexibilidade vis-à-vis o Estado, e com razão. Identificaram uma norma vital e insistiram numa retificação, recusando a justificação das autoridades. Obviamente, destacar o princípio em questão e descobrir se uma violação ocorreu frequentemente demandam uma intensa deliberação e geram uma considerável contestação.

Algumas vezes, contudo, os direitos humanos necessitam de implementação por política pública. Sinalizam, então, por um entendimento diferente. Os cidadãos, juntamente com o Judiciário, devem de forma geral ceder às autoridades. Aqueles podem normalmente processar estas somente por abandono ou arbitrariedade.

\footnotetext{
${ }^{209}$ Vera Vera vs. Ecuador, Ct. Inter-Am. D.H. (Ser. C) No. 224 (19 de maio de 2011), pp. 19-20 (II 43).

${ }^{210} I d$., p. 20 (II 44).
} 
Em Red Lion Broadcasting Co. v. FCC, ${ }^{211}$ por exemplo, um operador de "uma estação de rádio da Pensilvânia, WGCB," 212 desafiou a "doutrina de equidade (fairness)" da Comissão Federal de Comunicações (FCC) que "por vários anos impôs aos operadores de radio e televisão o requerimento de apresentar a discussão de questões públicas em estações de difusão, . . . de cobrir cada lado delas equitativamente [e] de destinar o mesmo tempo a todos os candidatos qualificados para cargos públicos," especialmente quanto "a ataques pessoais no contexto de questões públicas controversas." 113 A Suprema Corte dos Estados Unidos determinou que as autoridades não tinham limitado a "liberdade de expressão e de imprensa.",214

Unanimemente, sustentou "que o Congresso e a Comissão não violaram a Primeira Emenda ao requerer que uma rádio ou televisão dessem tempo de resposta a ataques pessoais e a editoriais políticos." 215 Também afirmou que:

Não há nada na Primeira Emenda que impeça o governo de requerer que um licenciado compartilhe sua frequência com outros e se conduza como representante ou fiduciário com obrigações de apresentar essas visões e vozes que são representativas da sua comunidade, as quais iriam, de outro modo, ser silenciadas. ${ }^{216}$

Em outras palavras:

Não viola a Primeira Emenda obrigar os licenciados, como beneficiários do privilégio de usarem as escassas radiofrequências e representantes de toda a comunidade, a dar tempo e atenção adequados a assuntos de grande interesse público. Condicionar a concessão ou renovação de licenças na intenção de apresentar visões representativas da comunidade sobre questões controversas é consistente com os fins e propósitos das disposições constitucionais que proíbem a limitação da liberdade de expressão e da liberdade de imprensa. ${ }^{217}$

De forma não surpreendente, os magistrados permitiram ao governo um amplo espaço de manobra:

Ao invés de entregar monopólios de frequência sobre um número de licenças relativamente pequeno, numa nação de 200.000.000, o governo certamente poderia decretar que cada frequência deveria ser compartilhada entre todos ou alguns daqueles que desejarem usá-la, sendo cada um responsável por uma porção diária ou semanal. A decisão e regulamentos em questão não vão muito longe. Eles determinam que sob circunstâncias específicas um licenciado deve tornar disponível uma razoável quantidade de tempo àqueles que têm uma visão diferente daquela que já foi expressa

\footnotetext{
211395 U.S. 367 (1969).

212 Id., p. 371.

${ }^{213}$ Id., pp. 369-370.

${ }^{214} I d .$, p. 386.

215 Id., p. 396.

${ }^{216}$ Red Lion, 395 U.S., p. 389.

${ }^{217}$ Id., p. 394.
} 
na estação. A expressão de um apoio político, ou de um ataque pessoal quando se tratar de uma questão pública controversa, simplesmente aciona esse compartilhamento de tempo. ${ }^{218}$

A decisão vai ao ponto de afirmar que as autoridades, além de exercerem a sua prerrogativa de lançar uma política nesse domínio, protegiam direitos essenciais da sociedade.

Afirma:

que o povo como um todo retém seu interesse na liberdade de expressão na rádio e seu direito coletivo a dispor dum meio que funcione consistentemente com os fins e propósitos da Primeira Emenda. É o direito de telespectadores e ouvintes, não o dos difusores, que é principal. ${ }^{219}$

A decisão a seguir especifica a natureza desse direito coletivo: "O direito do público a receber adequado acesso a ideias sociais, políticas, estéticas, morais e outras, além de experiências, é crucial aqui. Não pode ser constitucionalmente cerceado nem pelo Congresso, nem pela FCC." 220

Nessa área, o governo federal goza de ampla, mas não ilimitada, liberdade. Como exemplo disso, o Tribunal Supremo enunciou a sua disposição em reanalisar o caso no futuro se encontrar indícios de "auto censura" ou de omissão de "questões públicas controversas", como resultado de regulações oficiais. ${ }^{221}$ Anunciou que, "se a experiência com a administração dessas doutrinas indica que elas têm o efeito líquido de reduzir em vez de aumentar o volume e a qualidade da cobertura, haverá tempo adequado para reconsiderar as implicações constitucionais." 222 Os juízes ainda indicaram, assim, que a política seria então contraproducente e que mereceria repúdio. Além disso, eles teriam decidido contra o governo se tivessem descartado, como falsa, a premissa tecnológica da escassez de frequências. ${ }^{223}$

Numa nota similar, o parecer consultivo da Corte Interamericana em Exigibilidade do Direito de Retificação ou Resposta detalha como as autoridades devem implementar o direito

\footnotetext{
${ }^{218}$ Id., pp. 390-391.

${ }^{219}$ Id., p. 390.

${ }^{220} I d$.

${ }^{221}$ Red Lion, 395 U.S., p. 393.

$222 I d$.

${ }^{223}$ Ver id., p. 396 (“É argumentado que na hipótese de o governo escolher aqueles que melhor serviriam ao interesse público aos que dão voz a opiniões diferentes, dado que as frequências disponíveis para todos que as querem utilizar são escassas; ou mesmo dando acesso direto aos estúdios de broadcast; essa condição não mais prevalece, o que não justifica um controle contínuo."); $i d$., pp. 400-401 ("Em vista da escassez de frequências de emissão, . . . nós mantemos a regulação e a presente decisão está amparada tanto pelo estatuto quanto pela Constituição.").
} 
à resposta em programas ou publicações que ou distorçam fatos ou que causem ofensa. ${ }^{224} \mathrm{O}$ Artigo 14 da Convenção Americana de Direitos Humanos diz que: "Toda pessoa atingida por informações inexatas ou ofensivas emitidas em seu prejuízo por meios de difusão legalmente regulamentados e que se dirijam ao público em geral, tem direito a fazer, pelo mesmo órgão de difusão, sua retificação ou resposta, nas condições que estabeleça a lei." ${ }^{225}$ Consequentemente, implica a obrigatoriedade do direito de resposta. No entanto, concede flexibilidade às autoridades, desde que elas expressamente assegurem o direito "nas condições que a lei estabelecer."226

Em 1985, a Costa Rica pediu que a instância expusesse os princípios e as políticas públicas, por assim dizer, relacionados ao direito de resposta. Em particular, levantou, inter alia, as seguintes indagações: (1) "[O] direito consagrado no Artigo 14 da Convenção Americana sobre Direitos Humanos já está garantido em seu livre e pleno exercício a todas as pessoas que estão sob a jurisdição do Estado costa-riquense . . ? ;" 227 e (2) [T]em o Estado da Costa Rica um dever jurídico internacional de adotar, de acordo com os seus próprios procedimento constitucionais, medidas legislativas, ou outras, necessárias para efetivar o direito de retificação ou resposta previsto no Artigo 14 da Convenção. . . ?"228

O tribunal não hesitou em reforçar a natureza vinculativa do direito. Sublinhou que "o Artigo 14(1) da Convenção reconhece um direito de retificação ou resposta internacionalmente exigível. [O]s Estados Partes têm a obrigação de respeitar e garantir o livre e pleno exercício dele a toda pessoa sujeita à jurisdição deles." 229 De forma mais geral, "a Convenção busca de por si reconhecer direitos e liberdades . . . e não simplesmente facultar os Estados a fazê-lo."230 Os juízes repudiaram a visão de que o Artigo 14 "somente autoriza os Estados Partes a instituir o direito de retificação ou resposta por lei, sem obrigá-los. . .."231

\footnotetext{
${ }^{224}$ Exigibilidad del Derecho de Rectificación o Respuesta (arts. 14(1), 1(1) y 2, Convención Americana de Derechos Humanos), Parecer Consultivo OC-7/86, Ct. Inter-Am. D.H. (Ser. A.) No.7, (29 de agosto de 1986).

225 Convenção Americana supra nota 14, art. 14(1).

226 Id.

${ }^{227}$ Exigibilidad del Derecho de Rectificación o Respuesta (arts. 14(1), 1(1) y 2, Convención Americana de Derechos Humanos), Parecer Consultivo OC-7/86, Ct. Inter-Am. D.H. (Ser. A.) No.7, (29 de agosto de 1986), p. 3 (II 13).

${ }^{228} I d ., p .4$ (II 16).

${ }^{229} I d ., p .9$ (II $\left.2 \mathrm{~A}\right)$.

${ }^{230} I d .$, pp. 6-7 (II 24).

${ }^{231} I d$., p. 6 (II 23).
} 
No entanto, a maioria concedeu às autoridades uma liberdade significativa sobre os detalhes. Explicou que o Artigo 14 "requer o estabelecimento de condições para o exercício do direito ... por meio da 'lei', cujo conteúdo pode variar de um Estado para o outro, dentro de certos limites razoáveis e no marco dos conceitos afirmados pela Corte." 232 Os magistrados ainda esclareceram que o governo pode agir de acordo à discrição dele dentro desta estrutura sobreposta aos princípios desse direito.

O tribunal insistiu na compatibilidade da sua construção contextual com a eficácia do reforço do direito: "O fato de que Estados Partes podem fixar as condições para o exercício do direito ... não impede a exigibilidade, conforme o direito internacional, das obrigações contraídas. . .."233 "Em consequência, se, sob qualquer circunstância, o direito . . . não puder ser exercido por 'qualquer pessoa' sujeita à jurisdição de um Estado Parte, aconteceria uma violação da Convenção; suscetível a uma denúncia perante os órgãos de proteção previstos."234

Do mesmo modo, as autoridades devem implementar o direito à saúde através de política pública. Devem, assim, ter bastante liberdade de ação. Mais uma vez, podem sofrer condena se não aprovarem quaisquer medidas ou se procederem arbitrariamente.

Em Del Valle Bermúdez v. Ministério da Sanidade e Assistência Social, ${ }^{235}$ por exemplo, a Corte Suprema venezuelana analisou a política nacional oficial relacionada com o vírus da imunodeficiência humana (HIV) e a síndrome de imunodeficiência adquirida (AIDS). Ofereceu ao governo uma respeitável margem para erro. Como o Eixo Bolivariano lembraria, ele possui maior expertise e legitimidade para agir nesse domínio.

O tribunal mais alto da Venezuela primeiro verificou se a "negativa [do Ministério] de entregar os medicamentos necessários para o tratamento da doença [aos pacientes] de HIV/AIDS" colidiu com o direito à saúde. ${ }^{236}$ Curiosamente, essa questão parece tocar apenas no princípio. Parece não diferir muito da pergunta central em Instituto Rural Psiquiátrico e

\footnotetext{
232 Exigibilidad del Derecho de Rectificación o Respuesta (arts. 14(1), 1(1) y 2, Convención Americana de Derechos Humanos), Parecer Consultivo OC-7/86, Ct. Inter-Am. D.H. (Ser. A.) No.7, (29 de Agosto de 1986), p. 7 (II 27).

${ }^{233}$ Id., p. 7 (II 28).

${ }^{234} I d$. (II 28).

${ }^{235}$ Del Valle Bermúdez v. Min. of Health and Soc. Welfare, Rec. No. 15789 (Pol. \& Adm. Ch.) (Sup. Ct.) (Venez.) (1999), traduzido \& reimpresso em OQUENDO, supra nota 2, pp. 363-374.

${ }^{236}$ Id., p. 364.
} 
Vera. Em outras palavras, significou a recusa de atenção médica uma violação ao direito à saúde das vítimas?

Em Del Valle Bermúdez, os juízes venezuelanos inicialmente realizaram o inquérito de forma semelhante à dessas sentenças, previamente analisadas. Raciocinaram que "[existia] um evidente descumprimento [do] dever" da a administração quanto ao "direito à saúde" porque ela não "[supriu] correta e regularmente [as medicações receitadas] aos doentes. . .."237 Como resultado, o Ministério recebeu uma ordem judicial para "efetuar a entrega regular e periódica" de todas as medicinas prescritas, 238 "realizar ou pagar por testes especializados [ou outros]"239 e fornecer "todos os medicamentos para o tratamento de infecções oportunistas. . .."240

Não obstante, o Tribunal Supremo mudou de caminho, rumo ao centro da arena política. Primeiro, tornou sua decisão aplicável não somente aos requerentes mas também a outros cidadãos venezuelanos indigentes sofrendo "de HIV/AIDS" e em "necessidade de tratamento." 241 Segundo, compeliu as autoridades a "desenvolverem uma política de informação, tratamento e razoável assistência médica a favor dos requerentes" ${ }^{242}$ e, presumivelmente, a todos os outros indivíduos em situação similar.

Finalmente, destacou que, em razão da falta de uma cura conhecida e dos "altos" custos do tratamento, "a batalha contra a doença deveria focar na prevenção." ${ }^{243}$ Nessa frente, as autoridades tinham preparado "5000 folhetos," distribuído " 100.000 preservativos," cooperado com diversas organização cívicas contra a AIDS e lançado uma campanha pelo "sexo protegido". ${ }^{244}$ Os magistrados polidamente louvaram "essas medidas" como "uma iniciativa positiva que deveria continuar e ser intensificada," 245 mas no fim as consideraram insuficientes.

${ }^{237}$ Id., pp. 367-368.

${ }^{238}$ Id., pp. 372-373 (§ 1).

${ }^{239} I d$., p. 373 (Decisão (2)).

${ }^{240}$ Del Valle Bermúdez v. Min. of Health and Soc. Welfare, Rec. No. 15789 (Pol. \& Adm. Ch.) (Sup. Ct.) (Venez.) (1999), traduzido \& reimpresso em OQUENDO, supra nota 2, p. 373 (§ 4).

${ }^{241}$ Id., p. 372 . Ver também id., p. 374 (\$ 3).

${ }^{242} I d$., p. $373(\S 4)$.

${ }^{243}$ Id., p. 370 (Analysis (Right to Health, Life, and Access to Science and Technology)). ${ }^{244} I d$.

${ }^{245}$ Del Valle Bermúdez v. Min. of Health and Soc. Welfare, Rec. No. 15789 (Pol. \& Adm. Ch.) (Sup. Ct.) (Venez.) (1999), traduzido \& reimpresso em OQUENDO, supra nota 2, p. 370. 
Consequentemente, aconselharam que, "para um programa nacional de prevenção, a política que o Estado assuma a este respeito devia se desenvolver sobre as seguintes linhas. . ..246

- Programas educativos dirigidos a grupos vulneráveis como adolescentes, casais com problemas etc.

- Informação massiva à comunidade sobre a doença, suas causas, suas formas de transmissão e as medidas de prevenção.

- Elaboração de um plano nacional para facilitar o diagnóstico a preço acessível a través das instituições médicas do Estado. ${ }^{247}$

Ainda observaram:

Cada um desses programas requer uma preparação e uma execução especiais, tendo em conta diversos aspectos, tais como: informação geral sobre a doença, uso adequado de preservativos, emprego de inyectadoras e agulhas estéreis quando se utilizarem drogas, intervenção específica quanto aos grupos mais vulneráveis, trabalho contínuo a nível da comunidade, aconselhamento matrimonial. ${ }^{248}$

Terminaram a sua delineação das responsabilidades do réu nos seguintes termos:

Para este fim, o Ministério de Sanidade e Assistência Social deve fazer um estudo real das necessidades prioritários mínimas requeridas por esses pacientes e dos programas destinados a prevenir o crescimento dos índices de [infecção. Além do mais,] deverá o apresentar ao Presidente da República, em Conselho de Ministros, para que se tome em consideração na elaboração das orientações gerais para a formulação do Projeto de Lei do Orçamento para o próximo exercício fiscal. ${ }^{249}$

A ordem final expressamente exige a realização de tal pesquisa. Identifica o fim como "o desenvolvimento de uma política preventiva de informação, conscientização, educação e assistência integral a favor das pessoas que vivem com HIV/AIDS." ${ }^{250}$

Em tais questões políticas, os juízes obviamente deviam deferência ao governo. Como resultado, deviam validar qualquer plano oficial não-arbitrário. No entanto, finalmente

${ }^{246} I d$.

${ }^{247}$ Id., pp. 370-371

${ }^{248} I d$., p. 371.

${ }^{249} I d$.

${ }^{250}$ Del Valle Bermúdez v. Min. of Health and Soc. Welfare, Rec. No. 15789 (Pol. \& Adm. Ch.) (Sup. Ct.) (Venez.) (1999), traduzido \& reimpresso em OQUENDO, supra nota 2, pp. 373-374 (Writ of Protection (3)). 
condenaram as autoridades por causa da inabilidade ou relutância delas em formular qualquer estratégia. Ainda as instruíram a caminhar naquela direção e delinearam amplos parâmetros.

Apesar de ordenar um plano a longo prazo para tratar as vítimas e conter o avanço da enfermidade, deixaram os detalhes para o governo. Ao orientar sobre estes, permitiram as autoridades por si especificar, por exemplo, como cuidar dos enfermos, educar os indivíduos sob risco de infecção, informar a população em geral, oferecer diagnósticos económicos, capitalizar com os meios e informações disponíveis, elaborar o relatório requisitado e assim em diante.

Tendo exposto a ausência de uma estratégia oficial, exibiram pouca paciência com a alegação estatal de que, devido a limitações orçamentárias, tinha sido "impossível custear o tratamento em questão para todo o universo de pessoas que padecem de HIV/AIDS."251 Obrigaram o governo a realizar os ajustes necessários no orçamento com o objetivo de manter os seus compromissos constitucionais. ${ }^{252}$ Alertaram que não tinham opção a não ser "salvaguardar . . . o direito à saúde e à vida dos demandantes" e reforçar "os deveres de assistência social do Estado." 253

De forma subsequente a Del Valle Bermúdez, o judiciário venezuelano tem fundamentalmente mantido essa abordagem frente à crise da AIDS. ${ }^{254}$ Em toda América Latina, as cortes têm em regra lidado com tais pedidos de modo equivalente. ${ }^{255}$ No entanto, algumas delas têm se mostrado menos receptivos. Em contrapartida, os requerentes têm se direcionado e prevalecido em fóruns transnacionais. ${ }^{256}$ A discussão agora irá concentrar, no seu último “caso," em cinco petições.

\footnotetext{
${ }^{251} I d$., p. 368 (Analysis (Right to Health, Life, and Access to Science and Technology)).

${ }^{252}$ Id., pp. 369-370, 373.

${ }^{253} I d$., p. 368.

${ }^{254}$ Ver em geral OQUENDO, supra nota 2, p. 375-380. A última instância da Venezuela decidiu o caso Del Valle em 1999, durante o primeiro ano de Hugo Chávez na presidência. A Constituição venezuelana fundou uma nova Corte Suprema (Tribunal Supremo de Justicia) cujos juízes logo confrontaram adicionais pedidos de pacientes de AIDS. Em Glenda López v. Instituto Venezuelano para a Seguridade Social, traduzido \& reimpresso em id., pp. 375-379, alguns beneficiários, representados pelo mesmo grupo de advogados de antes, processou o Instituto para Seguridade Social por ter falhado em pagar e distribuir remédios para AIDS. A Sala Constitucional ressoou o tribunal anterior opinando que o réu havia "violado o direito à saúde, ameaçado o direito à vida, e o direito ao benefício do progresso tecnológico e científico." Id., p. 376 (Considerações (II)). Em 2002, confrontou uma ação virtualmente idêntica em Loreto Tabares v. Instituto Venezuelano dos Seguros Sociais. Não surpreende que o tribunal endossou “a Sentença Número 487 de 6 de abr. de 2001 (o caso Glenda López).” Id., p. 380.

${ }^{255}$ Ver em geral id., pp. 380-386.

${ }^{256}$ Ver id., pp. 384-385.
} 
Incapaz de persuadir a Corte Suprema do Chile numa tentativa prévia, pacientes de HIV/AIDS trouxeram a sua queixa para a Comissão Interamericana de Direitos Humanos e obtiveram uma liminar.

Na sua comunicação de 20 de novembro de 2001, a Comissão informou o Estado chileno de que as pessoas listadas precisavam com urgência de atenção básica das instituições estatais para conseguir a medicina necessária para o tratamento. Portanto, solicitou que ele adotasse medidas urgentes a fim de obter os medicamentos indispensáveis à sobrevivência dos indivíduos em questão, assim como os exames médicos que permitissem avaliar de maneira regular a saúde deles. ${ }^{257}$

A medida cautelar rapidamente produziu resultados concretos. "Em 5 de dezembro de 2001, o Estado informou acerca das diligências preliminares realizadas no Ministério da Saúde. Reportou que Juan Pablo Améstica, Manuel Orlando Farías e Náyade Orieta Rojas Vera já tinham recebido medicação e sido sometidos a exames para avaliar o estado de saúde deles a través de serviços estatais." 258

Vítimas de HIV/AIDS de El Salvador também recorreram à Comissão Interamericana. ${ }^{259}$ Obtiveram medidas cautelares em 29 de fevereiro de $2000 .{ }^{260}$ "Em 26 de junho de 2000, o Conselho Diretivo do Instituto Salvadorenho de Seguridade Social autorizou a aquisição da tripla terapia antirretroviral para portadores de HIV/AIDS." ${ }^{261}$ Os Comissários admitiram a petição em $2001 .{ }^{262}$ Elaboraram equivalentes injunções preliminares em favor de querelantes da Bolívia e Equador em 2002 e da Guatemala em 2005. ${ }^{263}$

Mais exatamente, Cuscul Pivaral vs. Guatemala, que admitiu a demanda, reconheceu que "o direito à saúde," como um direito à ação "curativa" e "preventiva", meramente aponta

\footnotetext{
${ }^{257}$ Cms. Inter-Am. D.H., Inf. Anual 2001 (Ch. III, (C) Sistema Peticiones y Casos Individuales, (1) Medidas cautelares acordadas o extendidas por la Comisión durante el año 2001, (b) Chile) OEA/Ser. L/V./II.114, doc. 5 rev. (2002), p. 1 (II 12).

${ }^{258} I d$.

${ }^{259}$ Miranda Cortez vs. El Sal. (Caso 12.249), Cms. Inter-Am. D.H.., Rel. No. 29/01, OEA/Ser. L/V/II.111, doc. 20 rev. (2001).

${ }^{260}$ Cms. Inter-Am. D.H., Inf. Anual 2001 (Ch. III, (C) Sistema Peticiones y Casos Individuales, (1) Medidas cautelares acordadas o extendidas por la Comisión durante el año 2000, (i) El Salvador) OEA/Ser. L/V./II.111, doc. 20 rev. (2001), p. 4 (II 30).

${ }^{261} I d$.

${ }^{262}$ Miranda Cortez vs. El Sal., Caso 12.249, Cms. Inter-Am. D.H., Rel. No. 29/01, OEA/Ser. L/V/II.111, doc. 20 rev. (2001), p. 9 (Decision) (II 1).

${ }^{263}$ Cms. Inter-Am. D.H., Inf. Anual 2002 (Ch. III, (C) Sistema Peticiones y Casos Individuales, (1) Medidas cautelares acordadas o extendidas por la Comisión durante el año 2002, (b) Bolivia \& (h) Ecuador) OEA/Ser. L/V./II.117, doc. 1 rev. 1 (2003), p. 2 (II 13), 9 (II 52); Cuscul Pivaral vs. Guat., Pet. 642-03, Cms. Inter-Am. D.H., Rel. No. 32/05, OEA/Ser. L./V/II.124, doc. 5 (2005).
} 
"uma obrigação de cumprimento progressivo."264 Todavia, alerta, do mesmo modo, que "existem ao menos duas situações de exigibilidade imediata."265 "O primeiro suposto é o da não-discriminação, no sentido de que o Estado não pode garantir o direito à saúde de maneira discriminatória." 266 "O segundo suposto se apresenta quando há um grave ou iminente risco de perda de vida pessoal, que o Estado deve garantir." ${ }^{267}$ Os Comissários estimaram que a disputa em questão poderia recair na última categoria e, consequentemente, concordaram em acolher o mérito do pedido."268

Inquestionavelmente, a Comissão estava contemplando o Artigo 26 da Convenção Americana no qual os "Estados Partes comprometem-se a . . conseguir progressivamente a plena efetividade dos direitos" econômicos, sociais e culturais "na medida dos recursos disponíveis." 269 Portanto, concedeu ao governo ampla liberdade de ação em tais matérias de política pública. No entanto, manteve ele pressionado por estar colocando seriamente em risco a sobrevivência dos requerentes.

As autoridades não têm que concretizar instantaneamente o direito à saúde. Porém devem elaborar um programa respeitável para uma realização gradual. O judiciário pode corretamente responsabilizá-las por essa obrigação. Além disso, deve adotar sanções na hipótese de inação ou arbitrariedade por parte delas.

Cuscul Pivaral parece presumir que as autoridades não desenvolveram nenhuma estratégia relacionada à doença. Assemelha-se a Del Valle Bermúdez na medida em que aparentemente ordena a administração da medicação prescrita como alívio provisório, enquanto o regime prepara seu planejamento de longo prazo. Nessa perspectiva, ambas as decisões fazem uma determinação de política de curto prazo na expectativa de que o governo eventualmente defina o curso permanentemente.

Em contraste, os tomadores de decisão em cada uma dessas duas controvérsias provavelmente não teriam tido objeções se se tivessem negado as medicações como parte de

\footnotetext{
${ }^{264} I d$., p. 9 (II 42).

${ }^{265} I d$., p. 9 (II 43).

${ }^{266} \mathrm{Id}$.

${ }^{267} I d .$, p. 9 (II 44).

${ }^{268}$ Cuscul Pivaral vs. Guat., Pet. 642-03, Cms. Inter-Am. D.H., Rel. No. 32/05, OEA/Ser. L./V/II.124, doc. 5 (2005), p. 9 (II 44).

${ }^{269}$ Convenção Americana, supra nota 14, art. 26.
} 
uma bem pensada alocação de recursos. Por exemplo, a administração poderia ter priorizado doenças mais difundidas, como câncer, ou com maiores chances de cura ou com tratamento mais barato, como malária, e aprovado apenas parte do financiamento da terapia para AIDS. Analogamente, poderia ter alocado recursos escassos de HIV/AIDS àqueles que, ceteris paribus, se beneficiariam mais, em outras palavras, os jovens. Mesmo que o órgão jurisdicional tivesse acreditado que essas escolhas estavam equivocadas, provavelmente as teria confirmado.

No entanto, os juízes não devem conceder ao governo carta branca sobre qualquer plano que ele puder elaborar. Por exemplo, poderiam rejeitar, como insuficientes do ponto de vista do direito à saúde, qualquer programa de AIDS que atendesse ao tratamento da enfermidade, mas não à prevenção. Del Valle Bermúdez teria certamente considerado esse tipo de estratégia irremediavelmente contraproducente e, como tal, inaceitável. Os Comissários Interamericanos teriam talvez reagido identicamente.

O Estado deve suportar um pesado onus probandi quando alega estar corretamente ocupando a esfera da política. As cortes devem corroborar que o regime tem honrado o princípio em jogo e que a política oficial geralmente cumpre com a norma correspondente. Podem muito bem gerar controvérsia de qualquer destas corroborações.

Quando cidadãos se direcionam à judicatura nacional ou internacional. para fazer valer os direitos humanos, podem parecer agir de forma não democrática. No entanto, essencialmente se engajam na democracia participativa na medida em que resolvem os assuntos por si mesmos ao invés de depender dos seus representantes. Claro, o objetivo não deveria consistir em começar uma discussão politicamente paralela, mas unicamente em garantir que o governo permaneça dentro dos limites delineados pelos direitos das pessoas. Além disso, a poder judicial deve conceder a ele o benefício da dúvida, ao menos em relação às questões de política pública.

As instâncias internacionais possuem um papel diferente daquele das nacionais. Em vista da distância geográfica e cultural, devem se comportar mais cautelosamente em relação às autoridades. De qualquer modo, se aplicam no caso normas especiais tanto processuais 
quanto materiais que ordinariamente impõem, direta ou indiretamente, tal dever de prudência. $^{270}$

Consequentemente, o bloco bolivariano pode legitimamente postular que o Sistema Interamericano de Direitos Humanos deve dar liberdade aos governos signatários, em geral, no que concernir à política, ao contrário do que for normativo. Segundo, os comissários, assim como os magistrados, devem dar crédito à corajosa cruzada em favor dos direitos à igualdade, dignidade, saúde, moradia e diversidade cultural. Finalmente, devem meticulosamente evitar sugerir que esses direitos importem menos que outros, como a liberdade de expressão.

Todavia, as nações descontentes não deveriam contar com o apoio irrestrito dos judiciários nacionais ou supranacionais. Pelo contrário, $\mathrm{s}$ devem aceitar que estes as investiguem e confrontem. Nas palavras de Viviana Krsticevic, Diretora Executiva do Centro para Justiça e Direito Internacional: “A Comissão," assim como a Corte, "deve seguir incomodando os governos; isso é um sinal de que está fazendo a sua tarefa."271

Os tribunais não devem operar como um ministério e, muito menos, como um lacaio das autoridades eleitas. Além disso, não precisam seguir a linha destas para o bem da consistência ou integridade da política governamental. Enquanto não têm de contê-las ou contrabalançá-las, devem pontualmente efetivar os direitos a pedido dos seus detentores. Devem empreender uma sondagem mais exigente em princípios e mais relaxada em políticas públicas, mas não pode abdicar completamente de suas responsabilidades em qualquer frente.

Inevitavelmente, juízes e a administração entrarão em conflito sobre direitos humanos. Sob o plano de fundo proposto, irão geralmente discordar se um caso particular se apoia em princípio ou política pública, no quê os princípios relevantes necessitam, assim como quais programas de implementação se qualificam como bona fide ou sensíveis. O governo irá provavelmente acusar a judicatura de decidir avidamente baseada em princípios, de interpretar estes ilegítima e muito amplamente e de classificar injustamente as estratégias políticas como

\footnotetext{
${ }^{270}$ Por exemplo, a Comissão e Corte Interamericana devem ordinariamente, como discutido na Seção I(B), supra, não admitir um pedido caso o requerente não tenha exaurido as instâncias nacionais.

${ }^{271}$ Eva Sáiz, La OEA, dividida ante la reforma de su órgano de derechos humanos, El PAís (7 de dez. de 2012) (citando Viviana Krsticevic).
} 
mera vaidade. Embora o esquema conceitual desenvolvido aqui certamente não erradique tais conflitos institucionais, pode ajudar a iluminá-los.

\section{CONCLUSÃO}

Este trabalho tanto interpretou quanto avaliou as chamadas objeções "bolivarianas" ao Sistema Interamericano de Direitos Humanos. Em primeiro lugar, as interpretou como sendo primordialmente não uma reivindicação de soberania ou uma declaração de insatisfação com a tomada de decisão institucional, mas sim um apelo à politização dos direitos humanos. Essa interpretação encontra suporte geral nos indícios disponíveis e torna o desafio geral ainda mais interessante.

Segundo, este artigo avaliou e questionou a solidez filosófica de uma tentativa de politizar os direitos em jogo. Recusou-se, no entanto, a responder com a afirmação de que os direitos humanos dependem essencialmente de princípios, e não de política pública. Pelo contrário, insistiu que os direitos humanos possuem tanto um componente político quanto normativo. Concluiu que os tribunais devem deferir quando tratar do primeiro, mas não quando se referir ao último, e ilustrou essa conclusão por meio de uma série de casos nacionais e internacionais que tocam sobre princípios e políticas públicas em torno à liberdade de expressão e ao direito à saúde.

Consequentemente, o bloco dissidente tem afirmado corretamente que os Estados merecem uma quantidade considerável de margem de manobra; não apenas como signatários dos tratados pertinentes, mas também como entidades com maior experiência e legitimidade em questões políticas. Além disso, tem protestado corretamente que o Judiciário não deve desprezar, de forma ideologicamente estreita, os fortemente politizados direitos de segunda geração; nem regimes que se concentram nesses direitos. Na verdade, à medida que as autoridades intensificam seu engajamento em nome de um direito humano de qualquer espécie, normalmente mergulham mais profundamente no campo da política e assim ampliam sua margem de discrição. 
Todavia, os juízes globais e locais não devem dar carta branca ao governo. Eles devem responsabilizá-lo caso ele proceda de forma arbitrária bem como caso não consiga realizar algum programa básico e essencial. De qualquer forma, devem examinar rigorosamente e sancionar severamente as autoridades se atropelarem o princípio subjacente a um direito específico.

Não devem se sentir compelidos a endossar a linha oficial. Ao contrário de um ministério de governo ou de uma agência administrativa, não têm nenhum dever de aliança com a administração no poder. Pelo contrário, devem se ater tenazmente a normas de direitos humanos e investigar prudentemente qualquer política proposta. Não precisam se opor nem mesmo conter as autoridades, mas devem investigar de forma independente.

Venezuela, Equador, Bolívia e Nicarágua poderiam, por sua parte, estar arguindo que estão majoritariamente buscando justiça social, que presumivelmente prevalece sobre os direitos humanos. No entanto, o exercício de estes geralmente contribui ou, ao menos, auxilia tal busca. Apenas sob extremas circunstâncias, se coloca no caminho dela.

Significantemente, nenhuma das determinações contestadas tem partido dum choque entre (1) o esforço para construir uma sociedade justa e (2) a obrigação de honrar os direitos humanos. De fato, outros países latino-americanos, como Brasil, Chile, El Salvador e Uruguai têm também progressivamente se comprometido com esta sem notar qualquer tensão com aquele. Como resultado, têm optado por sustentar, ao invés de desafiar, o Sistema Interamericano de Direitos Humanos, evidentemente vendo-o como capaz de acomodar substancial diversidade ideológica.

Por fim, alguém ainda pode resistir à tentação de conceber os direitos humanos como exclusivamente principiológicos ou políticos. No entanto, eles inevitavelmente possuem as duas características. Mais uma vez, as autoridades devem ter considerável, embora não absoluta, liberdade de ação quanto à dimensão política e quase nenhuma à principiológica.

De fato, o Eixo Bolivariano e seus inimigos convergem não apenas em rejeitar essa posição, mas também em abraçar uma sorte de utopia em relação aos direitos humanos. Nesse sentido, esperam uma harmonia permanente entre a judicatura e o a administração. Somente discordam se aquela deve ceder a esta - especialista em política pública -, ou o contrário, na 
medida em que a competência da judicatura reside na interpretação das normas. O Sistema Interamericano irá inegavelmente estagnar a menos que ambos os lados aprendam a viver em constante conflito na aplicação dos mencionados direitos e, em última instância, entre si.

Data de Submissão: 01/02/2021

Data de Aceite: 26/02/2021 